\title{
The position of case markers relative to possessive agreement
}

\author{
Variation within Hungarian
}

\author{
Éva Dékány 1
}

Received: 25 November 2015 / Accepted: 14 April 2017 / Published online: 5 September 2017

(C) The Author(s) 2017. This article is published with open access at Springerlink.com

\begin{abstract}
This paper inquires into two issues of Hungarian PPs. Firstly, when Hungarian pronouns bear an oblique case, the case marker must be followed by possessive agreement. Secondly, this pronoun-case-agreement order contrasts with the order found in garden variety possessive structures: ordinary possessive DPs feature the order noun-agreement-case. The goal of this paper is to offer an account of these puzzling phenomena. I argue that a PP structure in which PPs are projected from a silent PLACE noun and the Ground is merged as the possessor of PLACE (Terzi 2005, 2008, 2010; Botwinik-Rotem 2008; Botwinik-Rotem and Terzi 2008; Pantcheva 2008; Cinque 2010a; Noonan 2010, and Nchare and Terzi 2014) allows an enlightening analysis of the appearance and position of the possessive agreement in PPs. I also discuss how certain surface differences between PPs and ordinary possessive constructions can be accounted for while maintaining the possessive analysis of PPs. By showing that a PP structure with a possessive core yields a natural account of the intricate Hungarian data, the paper strengthens the case for a possessive-based approach to PPs in Universal Grammar.
\end{abstract}

Keywords PP · PLACE - Oblique case · Possessive structure - Possessive agreement

\section{Introduction}

It is well known that the relative order of agreement markers with respect to other morphemes shows considerable cross-linguistic variation both in the clause and within the noun phrase (see Ouhalla 1991; Julien 2002, 2007 and Ouali 2011 for

The original version of his article has been revised: The copyright has been corrected.

É. Dékány

dekany.eva@nytud.mta.hu

1 Research Institute for Linguistics, Hungarian Academy of Sciences, Budapest, Hungary 
the clause and Moravcsik 2003 for the noun phrase, among others). This paper examines why the Hungarian NP exhibits possessive agreement $>$ case order while the PP shows the opposite, case $>$ possessive agreement order.

The relevant data are as follows. In the Hungarian extended NP, the possessum agrees for the $\phi$-features of the pronominal possessor; the agreement precedes case suffixes. ${ }^{1}$

\section{az én szem-*(em)-ben}

the I eye-POSS.1SG-INE

'in my eye'

Hungarian pronouns in cases other than the morphologically unmarked Nominative must bear possessive agreement. As far as Accusative marked pronouns are concerned, only first and second person pronouns bear agreement. In standard Hungarian, first and second person singular pronouns do not bear an overt Accusative case suffix; they only have the agreement marker. Some dialects, however, feature the Accusative marker in this case, too (2a). First and second person plural pronouns have both the agreement marker and the Accusative case suffix (2b). In all cases when the agreement marker and the Accusative case marker co-occur, the morpheme order is as expected on the basis of (1): the case suffix follows the agreement marker.

$$
\begin{aligned}
& \text { a. eng-em-(\%et), tég-ed-(\%et), ő-t } \\
& \text { I-POSS.1SG-ACC you-POSS.2SG-ACC (s)he/it-ACC } \\
& \text { 'me, you(sg), him/her/it' } \\
& \text { b. mi-nk-et, ti-tek-et, o-k-et } \\
& \text { we-POSS.1 PL-ACC you-POSS.2PL-ACC (s)he/it-PL-ACC } \\
& \text { 'us, you(pl), them' }
\end{aligned}
$$

As for oblique marked pronouns, the case marker precedes the agreement (and pronouns bear agreement in third person as well).

$$
\begin{aligned}
& \text { én-benn-*(em) } \\
& \text { I-INE-POSS.1SG } \\
& \text { 'in me' } \\
& \text { te-hozz-*(ád) } \\
& \text { you-ALL-POSS.2SG } \\
& \text { 'to you' }
\end{aligned}
$$$$
\text { (4) te-hozz-*(ád) }
$$

$$
\begin{aligned}
& \text { ő-nál-*(a) } \\
& \text { (s)he/it-ADE-POSS.3SG } \\
& \text { 'at him/her/it' }
\end{aligned}
$$

The aim of this paper is to argue that this variation is epiphenomenal and can be given an enlightening analysis if we assume that PPs are projected from a silent PLACE noun. The discussion will proceed as follows. Section 2 lays out my assumptions about the syntax of case markers and the structure of PPs. Section 3 addresses the problem of why possessive agreement must appear on oblique pronouns. The order between oblique case suffixes and possessive agreement will be a major concern

\footnotetext{
${ }^{1}$ The paper uses the following abbreviations: ABL: Ablative case, ACC: Accusative case, ADE: Adessive case, ALL: Allative case, DAT: Dative case, DEL: Delative case, INE: Inessive case, PL: plural, PRT: verbal particle, PST: past tense, POSS: possessive marker, POSS.2SG: second person singular possessive agreement, SUBL: Sublative case, SUP: Superessive case.
} 
of mine in Section 4. Some differences that exist between PPs and ordinary possessive structures and so pose a potential challenge for the analysis will be accounted for in Section 5. Section 6 compares the present account to previous alternatives. The obligatory possessive agreement on Accusative pronouns as well as the order of that agreement and the Accusative case are the topic of Section 7. Section 8 summarizes the findings.

\section{Background assumptions about PP structure}

Recent research on the structure of case markers and adpositions converges on two conclusions that will be important for our purposes. Firstly, non-structural case markers and adpositions belong to the same syntactic category: that of Ps (Riemsdijk and Huybregts 2002; Asbury et al. 2007, among others). Secondly, PPs comprise multiple functional projections, and the structure of Path Phrases is built on the structure of Place Phrases (Jackendoff 1983; Zwarts and Winter 2000; Cinque 2010a; Den Dikken 2010; Koopman 2010; Svenonius 2010; Pantcheva 2011).

$$
\mathrm{P}_{\text {path }}>\mathrm{P}_{\text {place }}>\ldots
$$

Differing viewpoints abound about how many other projections there are besides PathP and PlaceP and what their label is. In this paper nothing hinges on this issue, so for the sake of simplicity I will only make use of PathP and PlaceP in the structural representation, noting that the analysis to be proposed is entirely compatible with further enrichment of the $\mathrm{P}$ heads in (6).

There is a long list of papers (including Terzi 2005, 2008, 2010; Botwinik-Rotem 2008; Botwinik-Rotem and Terzi 2008; Pantcheva 2008; Cinque 2010a; Noonan 2010 and Nchare and Terzi 2014) arguing that the PP-hierarchy is projected from a silent noun with a place semantics (PLACE), and the Ground is merged as the possessor of PLACE. ${ }^{2}$ This leads us to (7) as the full structure of PPs, with the Ground being merged as the complement of the silent PLACE noun. ${ }^{3,4}$

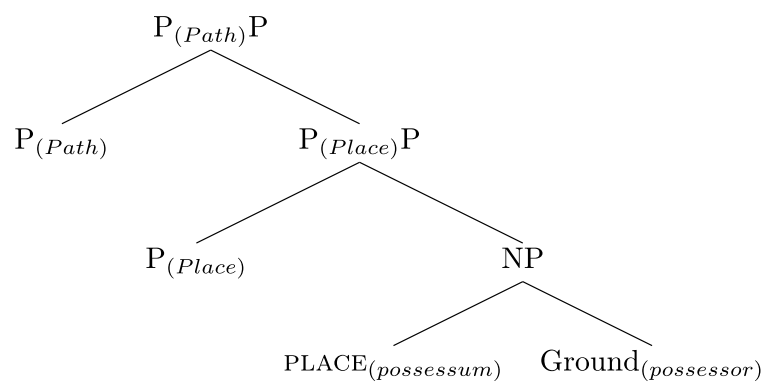

\footnotetext{
${ }^{2}$ See also Carstens (2008:150) for the claim that Bantu locative expressions contain a silent locative noun, “a sort of 'place' noun," and Katz and Postal (1964), Kayne (2004) and Collins (2007) for a similar analysis of here and there.

${ }^{3}$ In some languages PLACE is overt. The interested reader is encouraged to consult Cinque (2010a, fn. 5) and Nchare and Terzi (2014) for specific examples.

${ }^{4}$ See also Aboh $(2005,2010)$ for arguments for a possessive relationship in PPs.
} 
In this structure spatial adpositions and spatial case markers realize the Place and Path heads: those describing a static position spell out Place, while those describing a change of position (i.e. direction or route) spell out Path (see especially Riemsdijk and Huybregts 2002 and Asbury et al. 2007). ${ }^{5}$

\section{The obligatoriness of agreement with oblique pronouns}

\subsection{The agreement on oblique pronouns}

Hungarian has 18 case markers (see Kiefer 2000:580 for a list); these appear affixed to the noun.

az asztal-nál, az asztal-hoz, az asztal-tól

the table-ADE the table-ALL the table-ABL

'at the table, to the table, from the table'

Based on the case marked forms of nouns, we expect pronouns to also take case markers as affixes without further ado. This expectation, however, is not fulfilled.

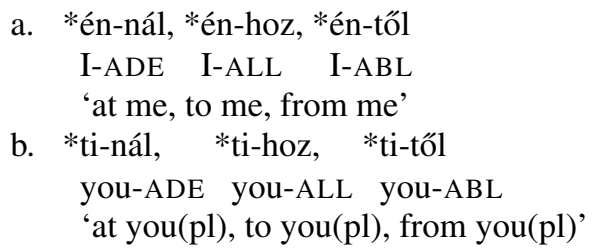

Instead of (9), we get the forms in (10): the pronoun itself is optional, and there is an obligatory agreement marker following the case marker. This agreement crossreferences the $\phi$-features of the optional pronoun. ${ }^{6}$
a. (én)-nál-am,
(én)-hozz-ám,
(én)-től-em
I-ADE-POSS.1SG I-ALL-POSS.1SG I-ABL-POSS.1SG
'at me, to me, from me'
b. (ti)-nál-atok, (ti)-hozz-átok, (ti)-tôl-etek you-ADE-POSS.2PL you-ALL-POSS.2PL you-ABL-POSS.2PL 'at you(pl), to you(pl), from you(pl)'

In Hungarian, the possessum features agreement for the $\phi$-features of pronominal possessors (lexical noun possessors do not trigger agreement on the possessum). The agreement that we find on oblique pronouns is the same as the agreement on ordinary possessums. Compare the pronominal agreement in (10) with the possessive agreement in (11) ${ }^{7}$

\footnotetext{
${ }^{5}$ See Roy and Svenonius (2009) for arguments that the Path over Place structure also applies to adpositions and cases with a non-spatial (temporal and causal) semantics.

${ }^{6}$ Three case markers have suppletive forms when they appear on pronouns. Two of these feature partial suppletion: the Elative is -ból/ból on lexical nouns and belól on pronouns, while the Illative is -ba/be on lexical nouns and bele on pronouns. The Superessive is the only synthetic case of the obliques, and it

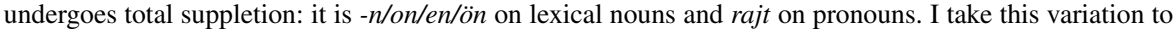
be contextually determined allomorphy.

${ }^{7}$ The definite article has two allomorphs: $a$ appears when the next word begins with a consonant, while $a z$ is used when the next word begins with a vowel.
} 

a. a(z én) sál-am, a(z én) fej-em
the I scarf-POSS.1SG the I head-POSS.1SG
'my scarf, my head'
b. a (ti) sál-atok, a (ti) fej-etek
the you scarf-POSS.2PL the you head-POSS.2PL
'your(pl) scarf, your(pl) head'

The full paradigms of possessive agreement and agreement on oblique pronouns are shown below. On ordinary possessed nouns, the possessive agreement is preceded by the possessive suffix ${ }^{8}$ and the plural marker. (Any overt case suffix would follow the agreement, as already shown above.) With a third person singular possessor the agreement is zero, but its presence can be detected by various tests (Bartos 1999). Possessive pronouns, including those in (12), can undergo pro-drop because the identity of the possessor is recoverable from the agreement morpheme.

agreement in ordinary possessives
a. az én makett-je-i-m
the I mockup-POSS-PL-POSS.1SG
'my mockups'
b. a te makett-je-i-d
the you mockup-POSS-PL-POSS.2SG
'your(sg) mockups'
c. az ô makett-je-i- $\varnothing$
the (s)he/it mockup-POSS-PL-POSs.3SG
'his/her/its mockups'
d. a mi makett-je-i-nk
the we mockup-POSS-PL-POSS.1PL
'our mockups'
e. a ti makett-je-i-tek
the you mockup-POSS-PL-POSS.2PL
'your(pl) mockups'
f. az ô makett-je-i-k
the (s)he/it mockup-POSS-PL-POSS.3PL
'their mockups'

Case markers have the exact same agreement paradigm as in (12) with one small caveat: cases that end in a consonant employ an overt -a/e allomorph in the third person singular. ${ }^{9}$ In spite of this allomorphic variation, the consensus view of the literature is that oblique pronouns bear the same agreement as the possessum.

\footnotetext{
${ }^{8}$ The role of the possessive suffix is to mark a noun as a possessum. This suffix is the exponent of the Poss head in the structure (see Bartos 2000). Observe that the possessive suffix is invariant across different persons and numbers, it is therefore not an agreement type of morpheme. When there is no plural marker on the possessum, then the possessive marker and the possessive agreement would end up string-adjacent. In this case if the possessor is first or second person, then the two suffixes are fused, and only the agreement marker is visible on the surface. This is what happens in (11), for instance.

${ }^{9}$ All agreement suffixes exhibit vowel harmony and are preceded by a linking vowel if the preceding morpheme ends in a consonant. These are regular phonological processes in the language.
} 
agreement on oblique pronouns

case ends in a $\mathrm{V}$
a. én rá-m
I SUBL-POSS.1SG
'onto me'
b. te rá-d
you SUBL-POSS.2SG
'onto you(sg)'
c. ő rá- $\varnothing$
(s)he/it SUBL-POSS.3SG
'onto him/her/it'
d. mi rá-nk
we SUBL-POSS.3PL
'onto us'
e. ti rá-tok
you SUBL-POSS.2PL
'onto you(pl)'
f. ő rá-juk
they SUBL-POSS.3PL
'onto them'

(14)

agreement on oblique pronouns case ends in a $\mathrm{C}$
a. én nál-am
I ADE-POSS.1SG
'at me'
b. te nál-ad
you ADE-POSS.2SG
'at you(sg)'
c. o nál-a
(s)he/it ADE-POSS.3SG
'at him/her/it'
d. mi nál-unk
we ADE-POSS.1PL
'at us'
e. ti nál-atok you ADE-POSS.2PL 'at you(pl)'
f. ő nál-uk they ADE-POSS.3PL 'at them'

\subsection{Caselike Ps are like oblique cases}

In the previous section we have seen that the order of possessive agreement and oblique case markers depends on whether these suffixes attach to a lexical noun or a pronoun. The schematic patterns are shown in (15).
a. N-Agr-Case
b. pronoun-Case-Agr

In addition to oblique case suffixes, a group of postpositions also has the curious distribution in (15). Hungarian has two types of postpositions. So-called caselike postpositions take a morphologically unmarked Ground, (16), and must immediately follow the Ground. ${ }^{10}$ So-called case assigning postpositions take an oblique marked Ground, (17), and do not have to immediately follow it (they can also be prepositional and may be P-stranded). ${ }^{11}$

\footnotetext{
${ }^{10}$ These Ps have grammaticalized from nouns bearing a locative, lative, or ablative case marker. The case suffixes in question have become obsolete and so do not productively combine with nouns anymore; native speakers treat caselike Ps as monomorphemic words. See Dékány (2011), Hegedús (2014) and Hegedús (2015) for discussion of the bimorphemic origin of these Ps.

${ }^{11}$ Caselike Ps are also known as dressed or agreeing postpositions, while case assigning Ps also go by the names case-governing, naked or non-agreeing postpositions. All of these labels, including the ones mentioned in the main text, are established in the literature, cf. Marácz (1989), Payne and Chisarik (2000), Asbury (2008), Dékány (2011), Hegedús (2006, 2013).
} 

a fal alatt
the wall under
'under the wall'

(17)
a fal-on át
the wall-SUP through
'through the wall'

Caselike postpositions share all syntactic properties of case markers, and differ from them only in their morphological integration into the noun: case markers are bound morphemes, while caselike postpositions are free morphemes. There is a fair amount of consensus by now that caselike postpositions and case markers belong to the same word class (Kenesei 1992; Marácz 1986; É. Kiss 1999, 2002; Asbury et al. 2007; Asbury 2008; Dékány 2011; Hegedûs 2013; Dékány and Hegedûs 2015). Some call this class $\mathrm{K}$, and view adpositions as morphologically free case markers, while others take this class to be $\mathrm{P}$, viewing case markers as morphologically bound postpositions. In either case, case markers and caselike postpositions are two sides of the same coin.

In this light, it is perhaps not surprising that the simple juxtaposition of pronouns and caselike postpositions is just as ungrammatical as the simple juxtaposition of pronouns an oblique case markers.
a. *én alatt, *én alá, *én alól
I under I under.to I under.from 'under me, to under me, from under me'
b. *ti alatt, *ti alá, *ti alól you under you under.to you under.from 'under you(pl), to under you(pl), from under you(pl)'

Instead of (18) we get (19): the pronoun is optional, and there is obligatory possessive agreement following the postposition.
a. (én) alatt-am,
(én) alá-m,
(én) alól-am
I under-POSS.1SG, I under.to-POSS.1SG I under.from-POSS.1SG 'under me, to under me, from under me'
b. (ti) alatt-atok,
(ti) alá-tok,
ti alól-atok
you under-POSS.2PL, you under.to-POSS.2PL you under.from-POSS.2PL 'under you(pl), to under you(pl), from under you(pl)'

The facts in (10) and (19) pose four questions. The pronoun is supposed to be the stem to which the case suffix attaches, so why is it optional? Why is the agreement obligatory? Why is it the same agreement as that of the possessum? Why is it that in (10) and (19) the case precedes the agreement, while in ordinary possessive structures such as (20) it follows the agreement?
az én sál-am-hoz,
a ti fej-etek-tôl
the I scarf-POSS.1SG-ALL the you head-POSS.2SG-ABL
'to my scarf, from your(pl) head' 
We will address these questions in Section 3.4. In order to lay the groundwork for the analysis, in the following section we will establish that possessive agreement is only one of the similarities between possessive constructions and pronouns bearing an oblique case or caselike $\mathrm{P}$.

\subsection{Possessive-like properties of oblique PPs and caselike Ps beyond agreement}

In this subsection I will survey three parallelisms that hold between PPs and ordinary possessive constructions beyond the presence of possessive agreement. The first similarity concerns the shape of the 3PL pronoun, ók. Ók is transparently composed of the $3 \mathrm{SG}$ pronoun $o$ and the ordinary plural marker $-k$. It triggers plural agreement on the predicate, as expected.

$$
\begin{aligned}
& \text { o-*(k) ír-nak/magas-ak } \\
& \text { (s)he/it-PL write-3PL/tall-3PL } \\
& \text { 'they write/are tall' }
\end{aligned}
$$

When the 3PL pronoun serves as an unmarked possessor, a so-called anti-agreement effect arises. Ók is obligatorily replaced by its singular counterpart, ó, and the plurality of the possessor is indicated only by the possessive agreement on the possessum.

$$
\begin{aligned}
& \text { az ö- }(* \mathrm{k}) \quad \text { kard-juk } \\
& \text { the (s)he/it-PL sword-POSs.3PL } \\
& \text { 'their sword' }
\end{aligned}
$$

3PL pronouns bearing an oblique case or a caselike $\mathrm{P}$ are also obligatorily replaced by the singular form, $\not$, and the plurality of the pronominal Ground is indicated only by the possessive agreement following the case (23) or the adposition (24).

$$
\begin{aligned}
& \text { ő-(*k) hozzá-juk } \\
& \text { (s)he/it-PL ALL-POSS.3PL } \\
& \text { 'to them' }
\end{aligned}
$$

ő- $(* \mathrm{k}) \quad$ alatt-uk (s)he/it-PL under-POSS.3PL 'under them'

The second similarity holds between 'discontinuous possessives' and 'discontinuous PPs'. Ordinary possessors may be either morphologically unmarked or Dative marked (25). The possessum agrees only with pronominal possessors; if the possessor is a lexical noun, only the so-called possessive suffix is present.
a. a lány-ok ajándék-a the girl-PL gift-POSS 'the girls' gift'
b. a lány-ok-nak az ajándék-a the girl-PL-DAT the gift-POSS 'the girls' gift'

Of the two types of possessors, the Dative possessor may appear separated from the possessum, too. If the external Dative possessor is a plural lexical noun, then the 
possessum may show either singular of plural agreement. ${ }^{12}$

a. A lány-ok-nak meg-jött az ajándék-a.

the girl-PL-DAT PRT-came the gift-POSS.3SG

'The girls' gift has arrived.'

3SG agreement

b. A lány-ok-nak meg-jött az ajándék-uk. the girl-PL-DAT PRT-came the gift-POSS.3PL

'The girls' gift has arrived.'

3PL agreement

As for discontinuous PPs, caselike Ps must be in the immediately postnominal position (27) and they disallow P-stranding (28).

(*előtt) szinte (*előtt) a lány-ok (*szinte) előtt

in.front.of almost in.front.of the girl-PL almost in.front.of 'almost in front of the girls'
a. *Mari elótt men-t a lány-ok.
Mary in.front.of go-PST.3SG the girl-PL
'Mary went in front of the girls.'
b. *A LÁNY-OK men-t Mari előtt.
the girl-PL go-PST.3SG Mary in.front.of
'It was the girls that Mary went in front of.'

However, a special, marked construction, one that resembles the external possessive construction in (26), makes it possible for the caselike $\mathrm{P}$ to be separated from the Ground. For this to happen, the Ground must bear Dative case and the P must show agreement (Marácz 1984; É. Kiss 1998; Surányi 2009a,b; Rákosi and Laczkó 2011; Rákosi 2012). Agreement with a plural Ground may be either singular or plural.
a. Mari előtt-e
men-t
a lány-ok-nak.
Mary in.front.of-POSS.3SG go-PST.3SG the girl-PL-DAT
'Mary went in front of the girls.'
b. Mari előtt-ük men-t a lány-ok-nak.
Mary in.front.of-POSS.3PL go-PST.3SG the girl-PL-DAT
'Mary went in front of the girls.'

What is common to the external possessive construction and discontinuous PPs is that surface non-constituency requires Dative case and allows agreement possibilities that are disallowed under surface adjacency. ${ }^{13}$ I will come back to the analysis of these constructions in Section 5.2.

\footnotetext{
${ }^{12}$ Den Dikken (1999) argues that (26a) features default agreement on the possessum, while in (26b) there is a resumptive pro possessor inside the DP and there is regular agreement on the possessum. I will return to these data in Section 5.2. For a recent discussion of Hungarian external possessives, see É. Kiss (2014).

${ }^{13}$ Case markers may also appear in discontinuous PPs. In this case, however, a reduplication-like structure arises: the case marker appears both on the Ground and in a second position that is separated from the Ground (É. Kiss 2002; Surányi 2009b; Rákosi 2014). Just like with separated caselike Ps, separated case markers must bear agreement and may show either singular or plural agreement with plural nouns.
}
(i) a. Mari hozz-á ér-t a lány-ok-hoz.
Mary ALL-POSS.3SG touch-PST.3SG the girl-PL-DAT
'Mary touched the girls.'


The third similarity between possessive structures and PPs is that both pronominal possessors and pronominal Grounds can undergo pro-drop. (30) shows this for possessors, (31) for oblique case markers and (32) for caselike Ps.
az én szem-em-ben
/ a szem-em-ben

the I eye-POSS.1SG-INE / the eye-POSS.1SG-INE

both: 'in my eye'
a. én-benn-em, te-hozz-ád, ő-nál-a
I-INE-POSS.1SG you-ALL-POSS.2SG (s)he/it-ADE-POSS.3SG
'in me, to you, at him/her/it'
b. benn-em, hozz-ád, nál-a
INE-POSS.1SG ALL-POSS.2SG ADE-POSS.3SG
'in me, to you, at him/her/it'
én-alatt-am
/ alatt-am
I-under-POSS.1SG / under-POSS.1SG
both: 'under me'

To summarize, the similarities between possessive structures and PPs go beyond the presence of possessive agreement. In the following section I will put forth an analysis that can account for these parallels.

\subsection{PP agreement is agreement between PLACE and the Ground}

As discussed in Section 3.2, the possessive agreement in Hungarian PPs poses four questions. The pronoun is supposed to be the stem to which the case suffix attaches, so why is it optional? Why is the agreement obligatory? Why is it the same agreement as that of the possessum? Why is it that in PPs the case precedes the agreement (pronoun-case-agreement), while in ordinary possessive structures it follows the agreement ( $\mathrm{N}$-agreement-case)? I propose that the PP-structure in (7), repeated here as (33), offers a solution to all of these questions.

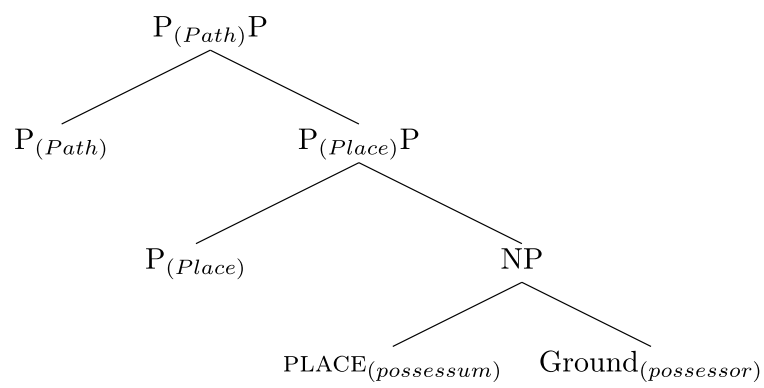

(33) involves an underlying possessive structure for PPs: PPs are projected from a silent PLACE noun, and the Ground, the element with respect to which the Figure

\footnotetext{
b. Mari hozzá-juk ér-t a lány-ok-hoz.

Mary ALL-POSS.3PL touch-PST.3SG the girl-PL-DAT

'Mary touched the girls.'
} 
is located, is merged as the possessor of PLACE. Case markers and caselike Ps that express a state are in the $\mathrm{P}_{\text {place }}$ head, while those expressing a change of state are in the $\mathrm{P}_{\text {path }}$ head. ${ }^{14}$

As a specific example, consider (34). Here the pronoun én 'I' is the Ground. It is therefore merged as the possessor of PLACE. The PLACE nominal is silent, which is signaled by $\emptyset$. The case marker and the caselike P express a state (a static location), therefore they are housed in the $\mathrm{P}_{(\text {Place })}$ head (35). ${ }^{15}$

$$
\begin{aligned}
& \text { a. (én)-nál-am } \\
& \text { I-ADE-POSS.1 } \mathrm{sG} \\
& \text { 'at me' }
\end{aligned}
$$

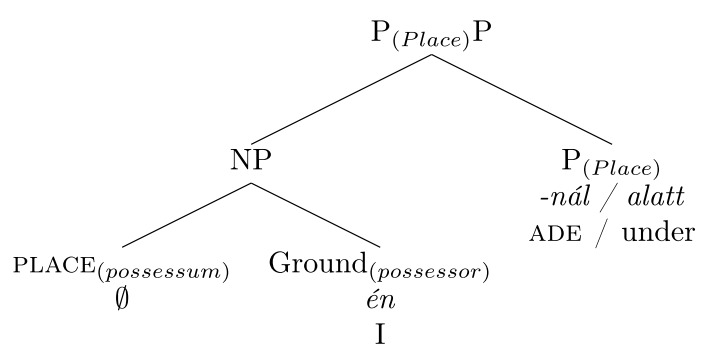

b. (én) alatt-am

I under-POSS.1SG 'under me'

The reason why there is obligatory possessive agreement on pronouns bearing an oblique case or a caselike $\mathrm{P}$ is that in Hungarian the possessum agrees with its pronominal possessor. As PLACE in (35) is a possessum, it agrees with its possessor if the possessor is a pronoun. The possessor of PLACE is the Ground, so PLACE shows $\phi$-feature agreement with a pronominal Ground. The structure of ordinary possessive constructions that (35) is modeled on will be taken up in detail in Section 4.1. I will return to the syntactic position of the agreement marker in PPs in Section $4.2 .{ }^{16}$

\footnotetext{
${ }^{14} \mathrm{~A}$ reviewer asks how case assigning Ps fit into the picture in (33). These Ps subcategorize for an oblique case marker (Superessive, Allative or Instrumental) and are thus higher in the extended PP structure than oblique cases or caselike Ps (Hegedús 2006, 2013; Dékány 2011). They are also projected from a silent PLACE noun with the Ground merged as the possessor of PLACE, but compared to (33), they involve additional structure at the top of the PP.

PPs headed by case assigning Ps also obligatorily feature possessive agreement if the Ground is a personal pronoun. The agreement appears after the subcategorized oblique case (as is normal for oblique cases) rather than on the $\mathrm{P}$ itself. This is illustrated in (i) with közel 'close to', a case assigning $\mathrm{P}$ that subcategorizes for the Allative case.

$$
\begin{aligned}
& \text { (én)-hozz-ám közel } \\
& \text { I-ALL-POSS.1SG close.to } \\
& \text { 'close to me' }
\end{aligned}
$$

${ }^{15}$ In the syntactic representations I use head-final structures for functional projections that host suffixes. One could, however, also derive the suffixal nature of these heads by positing head-first structures across the board plus a series of phrasal movements that bring together stems and suffixal functional heads.

${ }^{16} \mathrm{PPs}$ and possessive constructions have a lot in common cross-linguistically. Adpositional elements that show possessive agreement with the Ground also exist in several Uralic languages such as Khanty (Nikolaeva 1999:36), Mansi (Riese 2001:35) and Tundra Nenets (Nikolaeva 2014:ch. 8). Some Tzeltal (Mayan)
} 
The structure in (35) easily accounts for why the pronoun is optional in (34). Pronominal possessors in Hungarian routinely undergo pro-drop. This is possible because the possessum agrees with a pronominal possessor, so the unpronounced possessor is recoverable from the agreement. In (34) the pronoun is merged as a possessor, and so it may undergo pro-drop like possessors of ordinary nouns.

To summarize, adopting a possessive structure for Hungarian PPs immediately accounts for three of the four mysteries listed above. Firstly, agreement is obligatory on pronouns bearing an oblique case or caselike postposition because the Ground pronoun is merged as a possessor of PLACE, and Hungarian features agreement with pronominal possessors. Secondly, the agreement in the relevant structures is the same as possessive agreement because PPs involve a possessive structure. Thirdly, the pronoun is optional because as a possessor it may undergo regular pro-drop. The real stem of the case marker or caselike $\mathrm{P}$ is not the pronoun, but PLACE.

The different behavior of pronouns and lexical nouns in oblique PPs also follows from the account without auxiliary assumptions. We have seen that pronouns with an oblique case or caselike P are optional, and there is obligatory agreement in these PPs. These properties do not carry over to lexical nouns with an oblique case or caselike P. The noun and the case or caselike P are simply juxtaposed, the noun is not optional, and there is no agreement.
a. János-nál, János-hoz, János-tól
John-ADE John-ALL John-ABL
'at John, to John, from John'
b. az autó-n, az autó-ra, az autó-ról
the car-SUP, the car-SUBL the car-DEL
'on the car, onto the car, from (on) the car'

The lexical nouns in (36) are merged as possessors of PLACE.

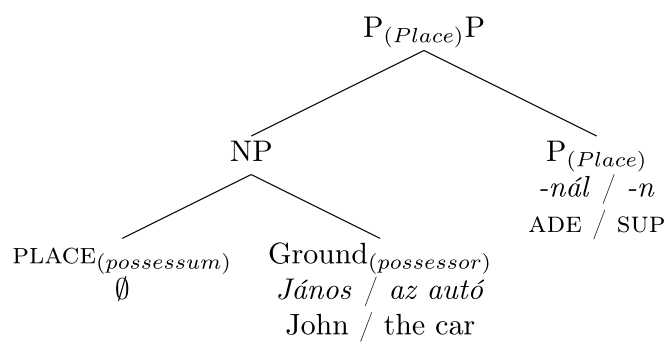

The possessum does not agree with lexical noun possessors in Hungarian, therefore PLACE does not agree with a lexical noun Ground. In absence of an agreement

\footnotetext{
Ps are prefixed by the possessive marker (Svenonius 2006), and Welsh prepositions take possessive clitics (a cross-Celtic pattern, cf. Borsley et al. 2007). The Ground NP is marked identically to possessors in many languages (see Dékány 2011:139 for a list). The discussion of these languages lies outside the scope of this paper. Importantly, beyond the morphological similarities, Hungarian PPs also show syntactic parallels with possessive constructions, and the variation in the order of case and possessive agreement also needs to be addressed.
} 
marker, lexical noun possessors must have an overt realization, so the lexical nouns in (36) cannot remain covert.

The fourth question with regard to oblique cases and caselike Ps is how to capture the variation in morpheme order between ordinary possessive noun phrases (nounagreement-case) and PPs (pronoun-case-agreement). I take up this issue in the next section.

\section{Deriving the variation in morpheme order}

I propose that understanding how the surface word order of ordinary possessive structures is derived in Hungarian provides the key to understanding the morpheme order variation between case markers/caselike postpositions and possessive agreement. In this section I will first map out the underlying structure of ordinary possessives and the movements that derive the surface word order of these constructions (Section 4.1). Then I turn to PPs, and show how the possessive analysis can derive the pronouncase-agreement order for oblique pronouns (Section 4.2) and the noun-agreementcase order for oblique marked R-expressions (Section 4.3).

\subsection{The structure of ordinary possessive noun phrases}

A schematic base-generated structure of ordinary possessive constructions is given in (38). FP stands for functional projection, the role of which will become clear below.

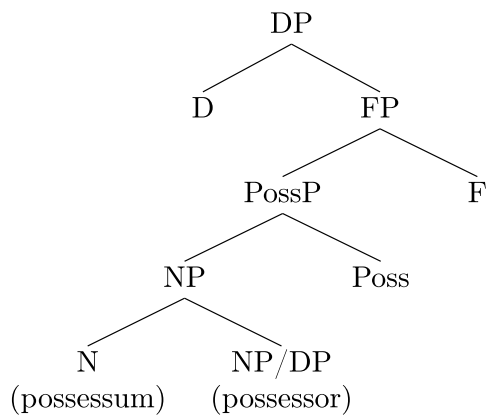

The noun phrase with the possessor role is merged as a complement to the possessum. ${ }^{17}$ NP is dominated by PossP. The Poss head hosts the possessive marker $-(j) a /(j) e$ (see Szabolcsi 1994; Bartos 1999, 2000; É. Kiss 2002). PossP is dominated by a phonologically null functional head, which I will call $\mathrm{F}$. The specifier of $\mathrm{F}$ hosts the (morphologically unmarked) possessor in its specifier. The possessive agreement

\footnotetext{
${ }^{17}$ There are differing viewpoints about what the base position of the possessor is in Hungarian. Szabolcsi and Laczkó (1992), Szabolcsi (1994) and Bartos (1999) take it to originate in a specifier, É. Kiss (2000) and É. Kiss (2002) assume that it can be merged either as a complement or as a specifier (see also Szabolcsi 1992 for the complement view), while Den Dikken (1999) argues that it is merged below the possessum in a predication structure. I will adopt the complement analysis here, noting that nothing crucial in this paper hinges on this choice. See also Botwinik-Rotem (2008), Botwinik-Rotem and Terzi (2008), Pantcheva (2008), Noonan (2010) and Nchare and Terzi (2014) for analyses in which the possessor of PLACE is a complement.
} 
features, which cross-reference the $\phi$-features of pronominal possessors, are bundled together with the F head. ${ }^{18}$ The FP, hosting the agreement marker, may be embedded under a DP projection.

As a specific example, consider (39). The underlying structure of this example is given in (40).
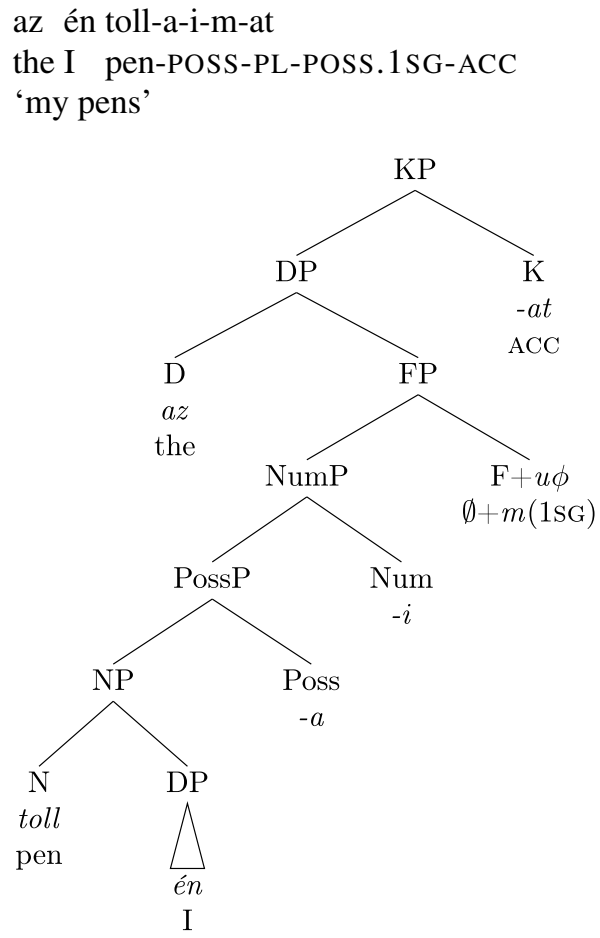

The surface structure involves movement of the possessor to a position on the left periphery of the DP: to spec, FP if the possessor is morphologically unmarked, ${ }^{19}$ and to a DP or KP-adjoined position if the possessor is Dative marked. For now, we will only be interested in morphologically unmarked possessors, and will come back to Dative marked possessors in Section 5.

\footnotetext{
${ }^{18}$ In the previous literature FP was standardly labeled as AgrP for 'agreement phrase.' The main reason why I am not adopting this label here is that Bartos (1999) has convincingly shown that lexical noun possessors do not elicit agreement on the possessum (see also É. Kiss 2002). (This case is to be distinguished from a phonologically zero agreement, which surfaces with pronominal third person singular possessors.) Therefore when the possessor is a lexical noun, it becomes clear that the phrase that hosts the (morphologically unmarked) possessor in its specifier cannot be projected by the agreement features, which are not present in the structure. This conclusion is also supported by the overall approach to agreement in the Minimalist Program, which has done away with Agreement Phrases. It must be emphasized, however, that the main reason why I do not adopt the AgrP label is empirical rather than theoretical.

${ }^{19}$ Morphologically unmarked possessors can be taken to bear Nominative case or to be caseless. For our purposes, it is immaterial which analysis is right (the interested reader is encouraged to consult Den Dikken 1999 and Dékány 2015 on this matter).
} 
(41)

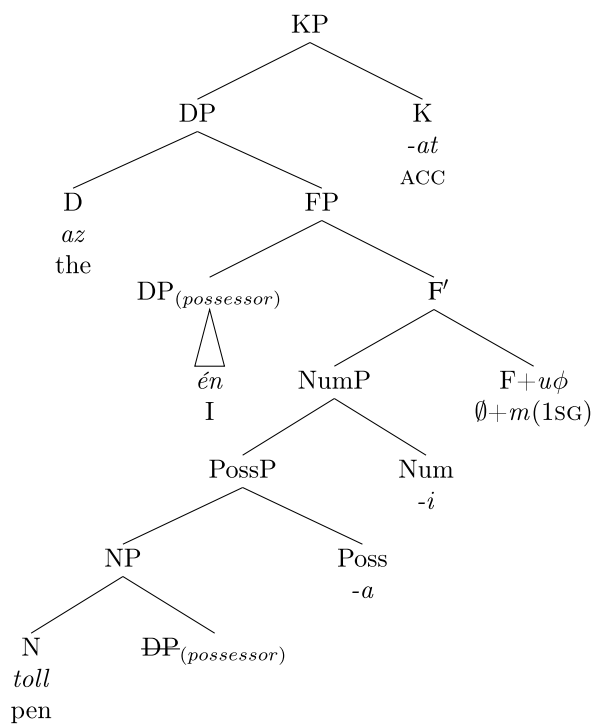

In the next section I will turn to the structure of PPs and show that assuming that they have a possessive core provides a principled way of deriving the pronoun-caseagreement order.

\subsection{The order pronoun-case-agreement in PPs}

Let us now examine the possessive agreement in PPs. (42) is a relevant example, with a pronoun bearing an oblique case and an agreement marker.

$$
\begin{aligned}
& \text { (én)-nál-am } \\
& \text { I-ADE-POSS.1SG } \\
& \text { 'at me' }
\end{aligned}
$$

The underlying structure of this example is (43). The pronoun that functions as the Ground (én) is merged as a possessor of PLACE. (The tree in (43) does not have a PossP. We will return to the status of PossP in PPs in Section 5.) The Adessive oblique expresses a static location ('at'), hence it is located in the Place head. Place is dominated by FP; the head of this projection hosts the agreement features that crossreference the $\phi$-features of pronominal possessors (i.e. pronominal Grounds), while its specifier serves as the landing site of the possessor (the Ground én).

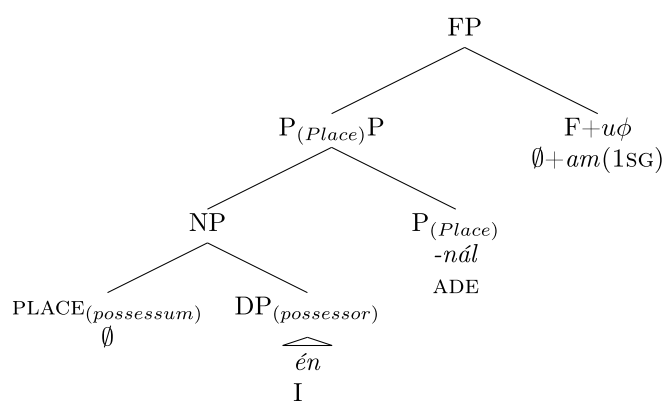


Like in ordinary possessive structures, the morphologically unmarked possessor undergoes movement to spec, FP. This yields (44) as the surface order.

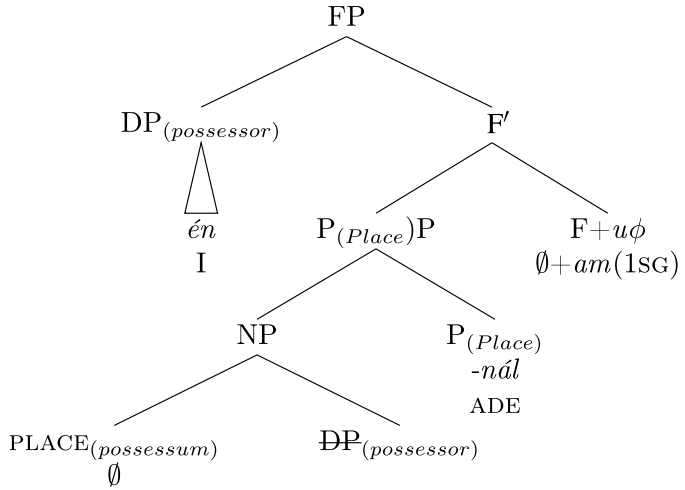

In (44), the noun that the case suffix truly belongs to is the silent PLACE. However, as PLACE has no overt pronunciation, the case suffix leans onto the closest overt element to its left. This element is the Ground, and so the case appears suffixed to the Ground, én. ${ }^{20}$ I will now turn to ordinary possessive constructions and show that their morpheme order, too, falls out from the present approach.

\subsection{The order noun-agreement-case in DPs}

Let us now examine why the order of the case marker and the agreement is reversed in ordinary possessive structures such as (45).

\footnotetext{
${ }^{20}$ This is in accordance with the general rules of Hungarian nominal morphology. Whenever the noun is unpronounced but its affixes are overt, those suffixes lean onto the rightmost overt element in the noun phrase and appear as suffixes of that element. Observe this phenomenon for the Accusative case suffix in (i) and the plural suffix in (ii). Note that the presence or absence (and in the latter case, the quality) of the linking vowel is determined by the host of the suffix, i.e. the last overt element in the noun phrase. The interested reader is encouraged to consult Laczkó (2007) and Lipták and Saab (2014, 2016) for analyses of this phenomenon.
}
a. négy szép nagy ház-at four nice big house-ACC 'four nice big houses'
b. négy szép nagy-(ház)-ot four nice big-house-ACC 'four nice big ones'
c. négy szép-(nagy ház)-et four nice-big house-ACC 'four nice ones'
d. négy-(szép nagy ház)-et four-nice big house-ACC 'four ones'
(ii) a. a szép fehér ház-ak the nice white house-PL 'the nice white houses'
b. a szép fehér-(ház)-ek the nice white-house-PL 'the nice white ones'
c. a szép-(fehér ház)-ek the nice-white house-PL 'the nice ones'


az én sál-am-nál

the I scarf-POSS.1SG-ADE

'at my scarf'

We will begin the discussion with the simplest scenario: when the Ground is a lexical noun, and there is no agreement marker present in the string, as in (46). Once the structure of such examples is in place, we will return to the more complex cases like (45).

$$
\begin{aligned}
& \text { a sál-nál } \\
& \text { the scarf-ADE } \\
& \text { 'at the scarf' }
\end{aligned}
$$

The structure of (46) is given in (47). As before, the Ground (here the noun phrase projected by the noun sál 'scarf') is merged as the possessor of PLACE, and it later undergoes displacement to the specifier of FP. The reader will recall that the possessum agrees only with pronominal possessors, and there is no agreement between the possessum and a lexical possessor. In (47), the possessor is a lexical noun, so there is no agreement between it and the possessum PLACE. That is, F does not bear agreement features in this case (marked with $\varnothing$ in the tree).

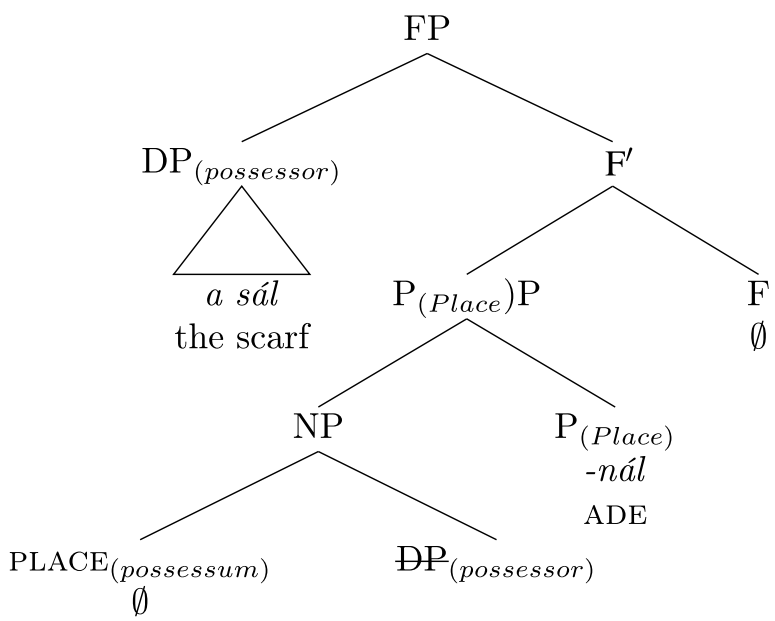

We can now return to the more complex case in (45), repeated here as (48).

$$
\begin{aligned}
& \text { az én sál-am-nál } \\
& \text { the I scarf-POSs.1SG-ADE } \\
& \text { 'at my scarf' }
\end{aligned}
$$

In this case, the Ground is the noun phrase az én sálam 'my scarf'; this is the entity with respect to which the Figure is located. What this means is that in this case the Ground is itself a possessive NP: within the noun phrase projected by sál 'scarf', there is a pronominal possessor, én, 'I', and agreement with that pronominal possessor. The internal structure of the Ground is shown in (49). 
(49)

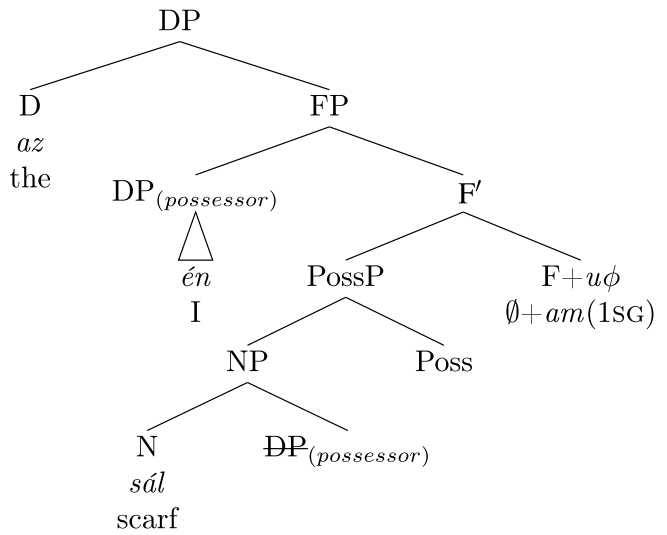

Within the PP in (48), (49) is merged as the possessor of PLACE.

(50)

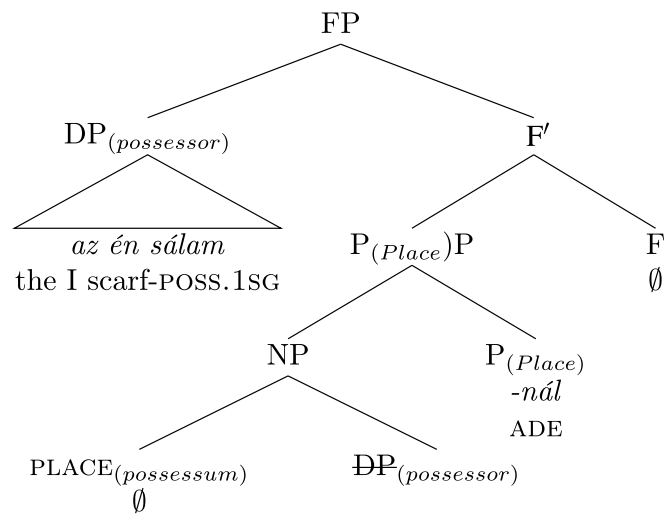

In (50), the possessor is a lexical noun (phrase) rather than a pronoun, so PLACE does not agree with it. This is why there are no agreement features on F and so no agreement follows the case marker.

The upshot of the proposed analysis is that the agreement suffixes in (51) and (52) reflect two different possessive relationships.

$$
\begin{aligned}
& \text { (én)-nál-am } \\
& \text { I-ADE-POSS.1SG } \\
& \text { 'at me' }
\end{aligned}
$$

az én sál-am-nál

the I scarf-POSS.1SG-ADE 'at my scarf'

The agreement in (51) reflects the agreement between PLACE and the pronominal Ground. In other words, this agreement 'belongs to' the PP. In (52), on the other hand, the agreement reflects a possessive relationship internal to the Ground. The morpheme order variation is thus epiphenomenal: the agreement in (51) and (52) have different functions and belong to different nouns (the one in (51) belongs to PLACE, while the one in (52) belongs to sál, the noun projecting the Ground).

The analysis presented above means that there are potentially two different positions where possessive agreement can be found in PPs: one internally to the Ground 
$\mathrm{DP}$, and one in the projection of PLACE. In principle, we should see these two agreements co-occur, as schematized in (53).

\section{[Ground $\mathrm{N}$-agreement ] PLACE-case-agreement}

Specific examples like (53), however, do not materialize, as the possessum agrees only with pronominal possessors. Suppose the Ground is a personal pronoun. Then there will be agreement between the pronoun and the PLACE noun, and it will appear after the case marker. However, there will not be possessive agreement within the DP projected by the pronoun (i.e. no agreement internal to the Ground). If, on the other hand, the Ground is a referential noun (which can have a complex internal structure containing a possessor and possessive agreement), then the PLACE noun will not agree for the Ground's $\phi$-features, and so no agreement will appear after the case marker. The two agreement markers thus cannot co-occur for independent reasons.

\section{Some differences between ordinary possessive structures and PPs and the nature of PLACE}

In the preceding sections I argued that the Ground is merged as a possessor of PLACE. In this section I will discuss the properties of PLACE and address the question of how two differences between PPs and ordinary possessive structures can be accounted for in the present proposal.

\subsection{The nature of PLACE}

I argued in line with much recent work that PPs are projected from PLACE, a silent noun. As often noted in the literature, the properties of PLACE are not fully identical to those of its overt counterpart, the common noun place. Similarly, in languages such as Shupamem ${ }^{21}$ that may use overt manifestations of PLACE in the form of locative nouns, these locative nouns are homophonous with ordinary nouns but have somewhat different properties from them (Nchare and Terzi 2014; see also Svenonius' 2006 discussion of the use of top or front as ordinary nouns and as parts of locative expressions). In particular, while common nouns are modified by adjectives and definite determiners, PLACE and overt locative nouns do not admit such modifiers: they are modified by Place, Path or Degree. I illustrate this below with Hungarian PPs.
a. *én jó-(PLACE)-nál-am
I good-PLACE-ADE-POSS.1SG
intended: 'at this good place of mine'
b. *ez én-(PLACE)-nál-am
this I-PLACE-ADE-POSS.1SG
intended: 'at this my place of mine'

\footnotetext{
${ }^{21}$ Shupamem is a Grassfields Bantu language. See Nchare (2012) for a grammatical description.
} 
It is generally conceded that while PPs have nominal properties, they are less 'nouny' than garden variety nouns. I will adopt the idea in Nchare and Terzi (2014) that this is because PLACE (and its overt manifestations in the languages that have them) is a 'light' or grammatical noun (see also Collins 2007). Light nouns are less lexical and referential than ordinary nouns and depend on a higher functional head for licensing and interpretation. In the case of PPs, this higher head is Place. That PLACE is less lexical than ordinary referential nouns accounts for why it cannot be modified by the same types of elements as the latter, as Nchare and Terzi argue. The less referential character of PLACE, I suggest, also accounts for why it cannot be referred back to the way garden variety referential nouns can.

Some researchers also argue that in spite of having a nominal core, the hierarchy of nominal functional heads in PPs is structurally deficient: Collins (2007) proposes that PLACE projects an impoverished structure, and Aboh (2010) argues that the possessive core of PPs is a truncated structure. If this is indeed on the right track, it likely follows from the less referential, light noun character of PLACE. In the next paragraphs, I will discuss how some differences between PPs and ordinary possessive constructions might follow from the former having a reduced nominal structure. At the same time, I will show that the differences are not as sharp as they might seem at first sight: under specific circumstances, ordinary possessive structures with a lexical noun possessum pattern with PPs in the relevant respects.

\subsection{The case of the possessor}

The first difference between PPs and garden variety possessive phrases concerns the case of the possessor. Ordinary possessors in Hungarian may be either Dative marked or morphologically unmarked (Szabolcsi and Laczkó 1992; Szabolcsi 1994; Laczkó 1995; Bartos 2000; É. Kiss 2002:ch. 7, a.o.). This is shown in (55a) for pronouns and in $(55 \mathrm{~b})$ for referential nouns.
a. [(én)-nek-em
a] / [az én] sál-am
I-DAT-POSS.1SG the / the I scarf-POSS.1SG
'my scarf'
b. [a sál-nak a] / [a sál] rojt-ja
the scarf-DAT the / the scarf thrum-POSS
'the scarf's thrum'

It appears to be the case, however, that the Ground may only be a morphologically unmarked possessor. If it could be a Dative possessor, too, then we would expect that the Dative case marker would be able to appear between the Ground and oblique case markers, contrary to fact.

$$
\begin{aligned}
& \text { a. *én-nek-nál-am } \\
& \text { I-DAT-ADE-POSS.1SG } \\
& \text { 'at me' }
\end{aligned}
$$
b. *sál-nak-nál scarf-DAT-ADE 'at the scarf'

The structure of the hypothetical (56a) is shown in (57). 


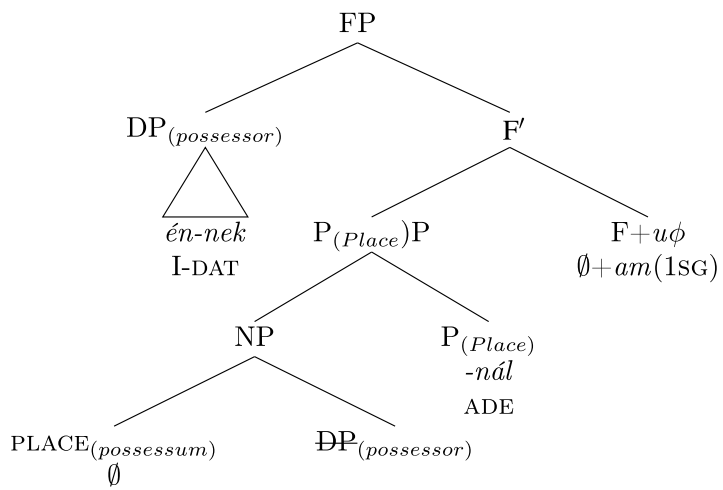

If the Ground is a possessor in the structure, why can it not bear Dative case? In the next paragraphs I will sketch two paths to an explanation that seem plausible.

Firstly, contrary to what is suggested by (57), Dative marked and unmarked possessors are not in the same structural position. Dative possessors are on the left edge of the DP: they precede the definite article and no DP-internal material can precede them. Unmarked possessors, on the other hand, are in a lower structural position, below D. Observe how the Dative possessor precedes and the unmarked possessor follows the definite article of the possessum in (55a). If light nouns indeed project a deficient nominal structure, then we can understand the lack of Dative possessors as non-projection of (or lack of licensing for) the phrase that hosts these possessors on the DP's left periphery.

At the same time, (56) does not make it necessary to appeal to structural impoverishment. On closer inspection it turns out that case marking on Hungarian possessors is more nuanced than it appears at first sight. Ordinary possessors may indeed be either morphologically unmarked or Dative marked, and there is no semantic difference between the two types of possessors. However, under certain conditions the case marking of the possessor may be restricted.

What is important for our purposes is that in certain types of possessive structures the possessor must be unmarked. These are (i) possessors in a descriptive possessive relationship (also called explicative Genitive construction), i.e. the city of Paris, the festival of Twelfth Night type of possessives, (58), (ii) possessors of numerals, as in English hundreds of people, (59), and (iii) temporal possessors, as in English this week's discoveries, (60). ${ }^{22}$

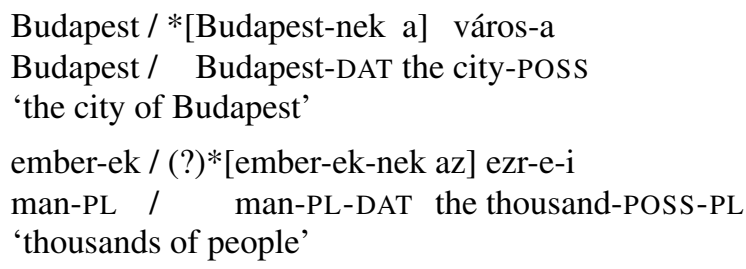

${ }^{22}$ For the sake of completeness, I note here that there are also types of possessive relationships in which the possessor must be Dative marked. Demonstrative pronouns, the indefinite interrogative pronouns $k i$ 'who' and $m i$ 'what', and relative pronouns are all ungrammatical as unmarked possessors. See Bartos (2001) and Den Dikken and Dékány (to appear) for possible analyses. 
a hét / [*a hét-nek a] kép-e

the week / the week-DAT the picture-POSS

'the picture of the week'

There is no significant contribution in the literature on why the Dative possessor is impossible (58) through (60), and it is difficult to see what the common denominator to these possessive phrases is. The property that the restriction makes reference to appears to be different in all three cases. In (58) it is the identity relationship that holds between the possessor and the possessum that is crucial. In (59) the restriction makes reference to the word class of the possessum, while in (60) the restriction is due to the denotation of the possessor. These restrictions on the case marking of the possessor remain one of the most poorly understood aspects of Hungarian nominal syntax.

The impossibility of Dative marking on the Ground may very well be similar to what we see in (58)-(60). If so, then the restriction on possessor case in PPs must be rooted in the possessum (as both personal pronouns and referential nouns can be either unmarked or Dative marked possessors with an ordinary noun possessum). That is, Dative possessors are disallowed when the possessum is PLACE. We see a similar restriction when the possessum is a numeral (59). PLACE and numerals have in common that they both have nominal properties but are less 'nouny' than ordinary referential nouns. It is possible that this property is directly responsible for the lack of Dative possessors, but I leave this matter for further research. What is important for our purposes is that genuine possessors can be excluded from the Dative possessor position under certain circumstances.

As already mentioned in Section 3.3, the Ground may bear Dative case under special circumstances, though. For this to happen, it must appear PP-externally, and if it bears plural marking, the agreement on the $\mathrm{P}$ can be either singular or plural.

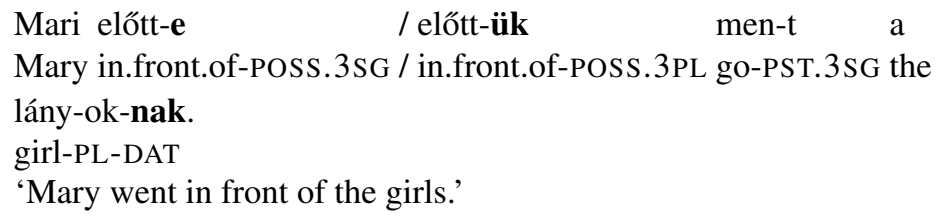

This pattern is very similar to what we see in discontinuous ordinary possessive constructions: an external possessor is always Dative marked, and if it bears plural marking, the agreement on the possessum can be singular or plural.
A lány-ok-nak meg-jött a könyv-e
/ könyv-ük. the girl-PL-DAT PRT-came the book-POSS.3SG / book-POSS.3PL 'The girls' book has arrived.'

Den Dikken (1999) suggests that in (62) the possessor is generated externally to the DP. The singular agreement on the possessum is default agreement, while plural agreement arises when the external possessor binds a DP-internal plural pro possessor. I suggest to extend this analysis to the PP cases in (61). The Dative marked Ground is a Dative possessor generated outside of the PP. The PP is projected from the silent PLACE. PLACE is topped of by PlaceP housing the adposition, and FP host- 
ing the agreement is projected above PlaceP (see also examples (43) and (44)). The agreement is singular when no possessor is merged with PLACE and FP gets a default value, while agreement is plural when a (plural) resumptive pro possessor bound by the external possessor is merged with PLACE.

$$
\begin{aligned}
& [\text { FP [PlaceP [ PLACE ] elôtt }]-e] \ldots \text { Ground+Dat } \\
& \left.\left.\left[\text { FP [PlaceP [ PLACE pro }{ }_{i}\right] \text { elôtt }\right]-\ddot{u} k\right] \ldots{\text { Ground }+ \text { Dat }_{i}}
\end{aligned}
$$

In the following section we will see how the absence of the possessive marker can also be accounted for.

\subsection{The possessive marker}

The second difference between ordinary possessives and PPs concerns the possessive suffix: it is present in the former but appears to be absent in the latter type of structure. I will argue that this plausibly follows from the fact that PLACE is silent: the possessive marker disappears with a silenced ordinary noun possessum as well.

The possessive suffix is fused with the agreement if the possessum is singular and the possessor is a first or second person pronoun. Observe the lack of the possessive marker in (65).

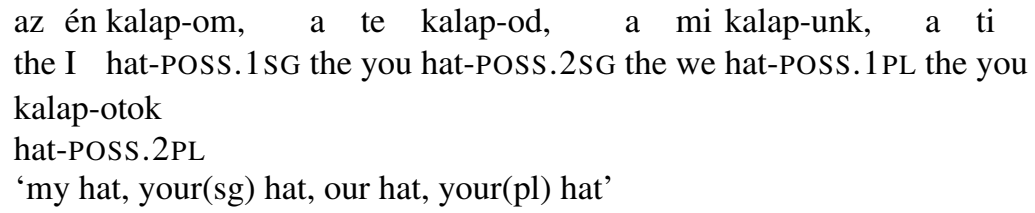

This fact could explain why we see only an agreement marker but no possessive suffix on first and second person pronouns with an oblique case or caselike $\mathrm{P}$ (66).

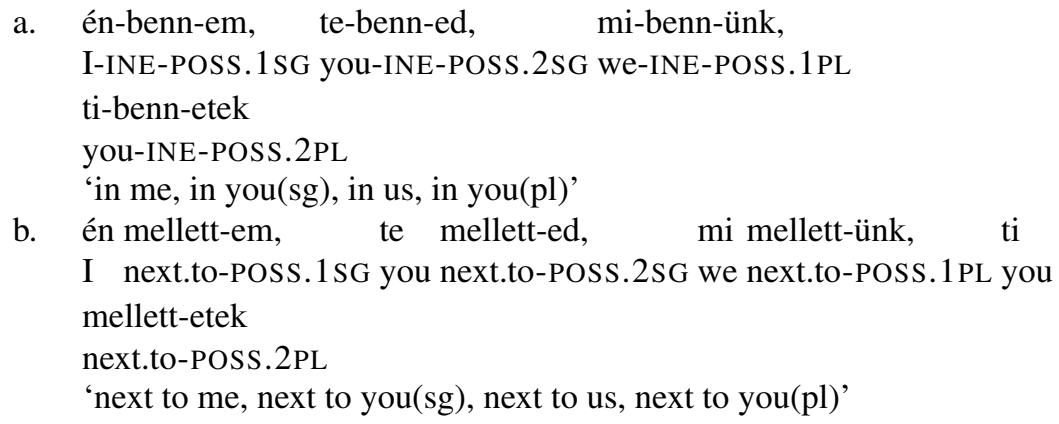

However, in ordinary possessives with a third person singular possessor the possessive marker does not fuse together with the agreement (arguably because the agreement is zero), and so the possessive marker is visible even with a singular posses$\operatorname{sum}(67)$.

$$
\begin{aligned}
& \text { az ô kalap-ja- } \varnothing \\
& \text { the (s)he/it hat-POSS-POSS.3sG } \\
& \text { 'his/her/its hat' }
\end{aligned}
$$


Furthermore, the possessive suffix is also always visible on the possessum when the possessor is a lexical noun: as the possessum does not agree with lexical possessors, the possessive suffix could not possibly fuse with the agreement in this case (68).

$$
\begin{aligned}
& \text { János kalap-ja } \\
& \text { John hat-POSs } \\
& \text { 'John's hat' }
\end{aligned}
$$

In light of this, we might expect the possessive marker to show up on third person singular pronouns and lexical nouns with an oblique case or caselike P. This, however, is not the case. ${ }^{23}$

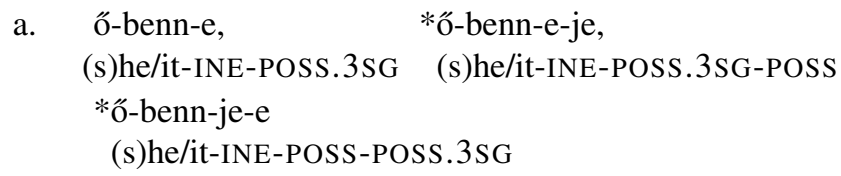

a. o-benn-e, *ő-benn-e-je, (s)he/it-INE-POSS.3SG (s)he/it-INE-POSS.3SG-POSS

*ö-benn-je-e

(s)he/it-INE-POSS-POSS.3SG 'in him/her/it'

b. ő alatt-e, *ő alatt-je-e, *ó (s)he/it next.to-POSS.3SG (s)he/it next.to-POSS-POSS.3SG (s)he/it alatt-e-je next.to-POSS.3SG-POSS 'next to him/her/it'
a. János-ban, *János-ban-ja, *János-ja-ban
John-INE John-INE-POSS John-POSS-INE
'in John'
b. János mellett, *János mellett-je
John next.to John next.to-POSS
'next to John'

There might be two reasons for this. Firstly, as mentioned before, the light noun PLACE may project a structurally deficient noun phrase. If so, then it is likely that (for speakers who disallow the examples in fn. 23), PossP is not projected in PPs to begin with. This would straightforwardly account for the lack of the possessive marker.

However, the pattern can also be explained without assuming that PLACE projects an impoverished structure. To wit, it is possible that the Poss head is present in the structure but it does not receive an overt lexicalization. It can be shown independently of PPs that the overtness of the possessive marker is dependent on the overtness of the possessum. An overt possessum requires an overt possessive marker (71).

\footnotetext{
${ }^{23}$ Dialectally we do find -ja/je on 3SG pronouns with an oblique case or with caselike P (É. Kiss 1998; Rákosi 2012). This happens with cases/caselike Ps ending in a vowel. No -ja/je is found with cases/caselike Ps ending in a consonant, or on lexical nouns with an oblique case or caselike P.
}

(i)
a.

(ô) rá-ja,

(s)he/it SUBL-POSS (s)he/it

hozzá-ja

ALL-POSS

'onto him/her/it, to him/her/it' 

a ti kalap-ja-i-tok
the you hat-POSS-PL-POSS.2PL
'your(pl) hats'

When the possessum is elided, however, then the possessive marker cannot be overt either (72). Observe that the elision of the possessum has no effect on the overtness of the plural marker or possessive agreement; only the presence/overtness of the possessive marker is affected. ${ }^{24}$

$$
\begin{aligned}
& \text { a ti-é-i-tek } \\
& \text { the you-é-PL-POSS.2PL } \\
& \text { 'your(pl) ones' }
\end{aligned}
$$

The lack of the overt possessive marker is thus plausibly just another instance of the phenomenon in (72): since PLACE is silent, the possessive marker does not appear on the surface either. ${ }^{25}$

\section{Comparison with previous approaches}

In the preceding sections I proposed a syntactic account of the morpheme order variation between (1) and (3), repeated here as (73) and (74).

$$
\begin{aligned}
& \text { az én szem-*(em)-ben } \\
& \text { the I eye-POSS.1SG-INE } \\
& \text { 'in my eye' }
\end{aligned}
$$

$$
\begin{aligned}
& \text { én-benn-*(em) } \\
& \text { I-INE-POSS.1SG } \\
& \text { 'in me' }
\end{aligned}
$$

The structure of Hungarian PPs has attracted significant interest (see Marácz 1986, 1989; Kenesei 1992; É. Kiss 1999; Creissels 2006; Hegedús 2006; Asbury et al. 2007; Asbury 2008; Trommer 2008; Rákosi 2010, 2012; Hegedús 2013). While all of these analyses mention that oblique pronouns bear agreement, and some of them propose an explicit structural position for the agreement, too, these analyses focus on positioning case markers in the functional structure of PPs, and none of them addresses the morpheme order variation between (73) and (74). With the (partial) exception of Rákosi (2010) and Rákosi (2012), none of them assume that contemporary Hungarian PPs have a genuine possessive structure either. ${ }^{26}$ Below I will compare my proposal in more detail to three of the alternative analyses that appear most relevant for my proposal.

\footnotetext{
${ }^{24}$ The status of the $-e$ suffix is debated: it is analyzed either as a case marker of the possessor or as a pronoun replacing the possessum. See Laczkó (2007), Bartos (1999, 2001) and Dékány (2015).

${ }^{25}$ Bartos (1999) and Bartos (2000) argue that the possessum and the possessive marker in (72) are colexicalized by $-e ́$ (i.e. they are fused and realized by one morpheme). This explanation could be extended to PPs, too: one could argue that the possessive marker is invisible in PPs because PLACE and the Poss head are co-lexicalized (by a null morpheme). I will not pursue this issue in detail here. The main point is that the possessive marker appears only with an overt possessum, and PLACE is not an overt possessum.

${ }^{26}$ Hegedús (2015) offers a diachronic study and argues that Hungarian PPs have grammaticalized from possessive structures. Crucially, she assumes that present day Hungarian PPs do not have a possessive structure anymore.
} 


\subsection{Spencer and Stump (2013)}

In a recent article Spencer and Stump argue that all morpho-syntactic approaches to (74) have an "essential arbitrariness" (p. 1245) and so are "inevitably and inherently flawed" (p. 1246). In their approach morphology is an autonomous component of grammar. They use an inferential and realizational model of morphology called Paradigm Function Morphology 2. Stripped to its essentials, their proposal is that nouns in ordinary possessive constructions, caselike postpositions and case markers all have the same agreement paradigm because "rules of person/number inflection ... apply indiscriminately to members of the natural class [-V]" (p. 1246).

They identify four main problems for syntactic analyses of (74). Firstly, there is agreement on finite verbs, too, but this agreement is different from the agreement found on possessed nouns, oblique pronouns, and caselike Ps. There is, however, no reason to expect that subject-verb agreement with a pronoun and possessive agreement with a pronoun will be phonologically identical. Verbal agreement features are bundled together with the verb or a verbal functional head, while possessive agreement features are bundled together with the noun or a nominal functional head. Just because both types of agreement features may be valued by pronouns, no expectation arises that they should have identical exponents.

The second argument against syntactic approaches is that the same morphology (i.e. the possessive agreement paradigm) fulfills different functions. When the agreement appears on a noun, it express the possessor's person and number. When the same agreement is on a caselike $\mathrm{P}$, it expresses the person and number of the pronominal complement. Finally, on case markers this agreement expresses "the pronoun's inflection for that case" (p. 1209). I argued that case markers and caselike Ps also have an underlying possessive syntax, so the possessive agreement paradigm does not fulfill different functions: in all the cases listed by Spencer and Stump, it expresses the possessor's person and number.

Spencer and Stump also consider it a major flaw of syntactic analyses that they cannot explain the lack of agreement on oblique lexical nouns. I argued that this is because the possessum does not agree with the $\phi$-features of lexical noun possessors in Hungarian, and so PLACE also does not agree for the $\phi$-features of a lexical noun Ground. In my analysis, in fact, it would be a problem if there was agreement on oblique lexical nouns, too.

The last major problem with syntactic approaches, according to Spencer and Stump, is that they cannot explain the allomorphy of the Elative, Illative, and Superessive cases mentioned in fn. 6 (they are -ból/böl, -ba/be, and -n/on/en/ön respectively on R-expressions, while they have the longer versions belól, bele, and rajt on pronouns). Explaining contextual allomorphy, however, is not the task of a syntactic analysis. Allomorphs and the contexts in which they are used are part of the vocabulary entries of individual morphemes, they thus belong to the lexicon rather than syntax. Given that whether or not a morpheme will have allomorphs and if so what their distribution is going to be is unpredictable, putting this information in the lexicon is the right move.

I hope to have shown that a syntactic analysis of Hungarian oblique pronouns and caselike Ps is not only possible, but it gives insights into the structure of PPs 
in general. Spencer and Stump's own analysis, on the other hand, is weakened by two sets of facts. They suggest that the same morphology (i.e. the possessive agreement paradigm) applies to members of the natural class [-V]. However, Hungarian infinitives may bear agreement (É. Kiss 1987; Tóth 2000), and when they do so, they take the same paradigm as a possessum. ${ }^{27}$ Since Hungarian inflected infinitives are not nominalized (for instance, they reject subordination by an adposition) and so can hardly be characterized as members of the natural class [-V], Spencer and Stump's empirical generalization must be reconsidered. In addition, the purely morphological analysis cannot give an explanatory account of the syntactic similarities between possessive structures and oblique cases and caselike Ps discussed in Section 3.3.

\subsection{Asbury (2008)}

Asbury's (2008) analysis uses the PP structure proposed by Svenonius (2006, 2010).

\section{[PathP Path [PlaceP Place [AxPrtP AxPrt [DP Ground-NP ]]]]}

Case markers and caselike Ps are hosted in the Place and Path heads. AxPrt, short for 'Axial Part,' is a functional head that has nominal properties. Agreement on oblique pronouns arises because AxPrt is endowed with uninterpretable number and person features that are checked with the Ground DP, the complement of AxPrt. In most cases, AxPrt in Hungarian fuses with another node in the morphological component, so there is no separate vocabulary item inserted under AxPrt. This is shown by the $\emptyset$ symbol. The structure of pronouns bearing oblique case markers is shown in (76b) (pronouns with a caselike $\mathrm{P}$ and lexical nouns with oblique cases or caselike Ps also have this structure.)

Asbury (2008:70)

a. o-benn-e

(s)he/it-INE-3SG

'in him/her/it' b.

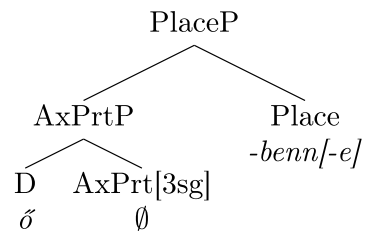

The agreement features, marked with square brackets, are on AxPrt, but in the linear string the agreement follows the case marker or caselike P sitting in Place or Path. This is problematic, though, as AxPrt is lower than Place and Path, and so we expect the agreement to precede the case marker or caselike P. Asbury (2008:69) argues that the agreement ends up on the Place or Path element "because there is no phonological material in Axial Part for the agreement morpheme to attach to." It is unclear, however, why the agreement does not simply attach to the Ground DP (apart from the fact that this would yield the empirically wrong pronoun-agreement-case

${ }^{27}$ See É. Kiss $(1987,2001,2002)$ for a possessive analysis of Hungarian infinitives, and Tóth (2002) and Rákosi and Laczkó (2008) for counterarguments showing that the two constructions are demonstrably different. 
order): as we have seen in fn. 20 , stranded affixes that require a host simply lean onto the element on their left; they never migrate across the element on their right.

Asbury's analysis and my own share the assumption that there is a nominal element in Hungarian PPs: AxPrt for her, PLACE for me. However, AxPrt and PLACE are not just two different names for the same element, and our analyses differ in some crucial respects. Let me start with a discussion of how AxPrt and PLACE are different. Firstly, while AxPrt is said to have nominal characteristics, it is a functional P-head, not a noun. PLACE, on the other hand, is a noun (albeit a light one) rather than a P-head. Secondly, they have a different semantics: PLACE is the "physical space surrounding" all of the Ground (Terzi 2010:197), while AxPrt identifies a "region ... based on the Ground element" and refers "to the front, back, top, bottom, sides, and middle of an object" (Svenonius 2006:52). That is, the denotations of PLACE and AxPrt are in a superset-subset relationship. ${ }^{28}$

Let me now turn to the differences between our analyses. Firstly, Asbury assumes with Grimshaw (2000) that the functional projections of PP are still in the projection line of N. In other words, AxPrt, case suffixes and adpositions are all in the extended projection of the Ground NP. This is not the case in my analysis. The extended projection of the noun phrase ends at DP (or KP, where K hosts the structural cases Nominative and Accusative, but crucially not spatial case markers or caselike Ps). PLACE starts a new extended projection, that of the PP. Case markers and caselike Ps are in Place and Path above PLACE, so they are not in the same extended projection as the Ground NP.

Relatedly, in Asbury's analysis the Ground is the complement of the lowest Phead. In my analysis it is not the complement of any P-type head. Instead, it is the complement of PLACE, which is a type of noun. In addition, in Asbury's proposal there is no real nominal element in spatial expressions beyond the Ground itself. In the present analysis, on the other hand, PPs involve a binominal structure.

Most crucially, Asbury does not assume a possessive syntax to PPs. She takes the Ground DP to be the object of the P (see p. 67, 75, a.o.) rather than a possessor. (Note that being a functional $\mathrm{P}$ head, AxPart could not be possessed in the first place.) This has the consequence that the parallels between PPs and ordinary possessive constructions surveyed in Section 3.3 are unaccounted for. In addition, in that analysis it is accidental that AxPart bears agreement features, and that the agreement markers in PPs have the same exponence as the agreement markers in possessive constructions. In the current analysis, it is crucial that there is a genuine possessive relationship underlying PPs, and the parallels between PPs and possessive constructions fall out without further ado. The presence of agreement in PPs is motivated by the underlying possessive structure of PPs, and the fact that PP agreement is identical to possessive agreement is predicted.

Finally, Asbury concedes that within the context of her own assumptions, "it remains a problem why the full noun does not induce overt agreement on Axial Part"

\footnotetext{
${ }^{28}$ For this reason, Cinque (2010b) uses both: PPs are projected from the noun PLACE, with the Ground as the possessor of PLACE, and AxPrt is one of the functional heads in the P-domain dominating PLACE. This is also perfectly compatible with the analysis of this paper (see also Dékány 2011).
} 
(p. 70). We have seen above that this fact is explained by my analysis because there is no agreement with lexical noun possessors.

\subsection{Rákosi $(2010,2012)$}

Rákosi's research is couched in an LFG-framework and focuses on so-called snake sentences (i.e. sentences of the type John saw a snake near him/himself) involving a caselike $\mathrm{P}$ in Hungarian. In standard Hungarian snake sentences involve a reflexive (77a). However, many speakers also accept a pronoun in first or second person (77b).

$$
\begin{aligned}
& \text { a. Lát-t-am egy kígyó-t maga-m mellett. } \\
& \text { see-PST-1SG a snake-ACC self-1SG beside } \\
& \text { 'I saw a snake beside myself.' } \\
& \text { b. Lát-t-am egy kígyó-t mellett-em. } \\
& \text { see-PST-1SG a snake-ACC beside-1SG } \\
& \text { 'I saw a snake beside me.' }
\end{aligned}
$$

(Rákosi 2010:397)

Rákosi argues that sentences like (77b) are possible because the PP in these examples has a complex internal structure. Specifically, it has a possessive structure: the caselike P mellett 'beside' is the head of the structure, and the pronoun is its possessor.

At the core, my analysis shares the intuitions behind Rákosi's proposal, but our analyses differ in two important respects. Firstly, Rákosi suggests that the possessive analysis of PPs is a marked option. All speakers have a simple, non-possessive lexical entry for caselike Ps. Some speakers, however, also have a second lexical entry for these Ps, one that has the possessive structure encoded in it. This second type of lexical entry is available only if the Ground is a pronoun. I suggested that PPs have a possessive structure for all speakers, regardless of whether the Ground is a pronoun or a lexical noun. Secondly, we use the silent PLACE element differently. Rákosi argues that the PLACE predicate is introduced within the lexical representation of the postposition, and the syntactic possessum is the postposition itself. On the other hand, I argue that PLACE is in the syntax: it is the possessum, and the postposition is in a higher functional head in the PP.

To summarize, in this section I argued that contra Spencer and Stump (2013), a syntactic approach to possessive agreement in PPs is both viable and superior to a morphological approach. I have also discussed in detail how the present approach is different from previous analyses. I hold that PPs have a possessive core in narrow syntax; they are projected from a silent PLACE noun with the Ground merged as a possessor. I will next turn to Accusative marked pronouns and the agreement that appears with them.

\section{Accusative pronouns}

The focus of the discussion so far has been the contrast between the morpheme orders in (78) and (79).

$$
\begin{aligned}
& \text { a sál-am-nál } \\
& \text { the scarf-POSS.1SG-ADE } \\
& \text { 'at my scarf' }
\end{aligned}
$$


(79)

(én)-nál-am

I-ADE-POSS.1SG

'at me'

(te)-nál-ad

you-ADE-POSS.2SG

'at you(sg)'
(81)

(ő)-nál-a

(s)he/it-ADE-POSS.3SG

'at him/her/it'

As already mentioned before, Accusative pronouns, too, must bear possessive morphology, but they contrast with oblique pronouns in two respects. Firstly, the order of the case marker and the possessive agreement is the same as on referential nouns, and secondly, third person Accusative pronouns do not bear possessive agreement. Instead, they are simply juxtaposed with the case marker (83).

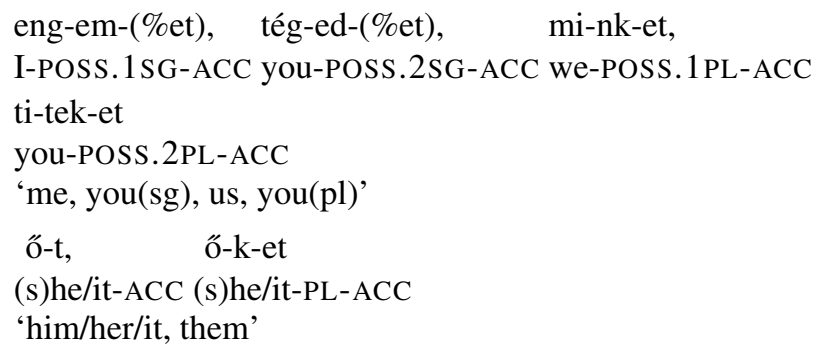

The explanation offered for oblique pronouns will not carry over to Accusative pronouns for two reasons. Firstly, the same structure could not derive the differences that we observe between the two kinds of pronouns. Secondly, Accusative is a structural case, and as such it is not associated with a PP structure. Instead, it involves a simple KP topping off the DP (84). Accusative pronouns thus require a different analysis than oblique ones.

$$
[\mathrm{KP}[\mathrm{DP} \mathrm{D}[\mathrm{NP} \mathrm{N}]] \mathrm{K}(\mathrm{Acc})]
$$

The structure of Hungarian Accusative pronouns is treated extensively in Den Dikken et al. (2001), Den Dikken (2004, 2006) and Den Dikken (2013). According to these analyses, Hungarian first and second person object pronouns project an internally complex DP that has a possessive structure. Den Dikken (2004) argues that within the object pronoun's DP, the first and second person pronoun itself is a possessum that has a (possibly null) clitic possessor (85). As expected from a possessum with pronominal possessors, the pronoun agrees with its possessor. This gives rise to the obligatory possessive marking on first and second person Accusative pronouns. (Third person pronouns project a simple, non-possessive DP. This accounts for the lack of possessive agreement on them.) This is shown in (85) (from Den Dikken 2004:ex. (36)).
a. $\left[N P * \mathrm{CL}_{[1 s g]}\right.$ eng+em ]
c. $\quad\left[N P * \mathrm{CL}_{[1 p l]} \mathrm{mi}+\mathrm{nk}\right]$
b. $\quad\left[N P * \mathrm{CL}_{[2 s g]}\right.$ tég+ed ]
d. $\quad\left[N P * \mathrm{CL}_{[2 p l]} \mathrm{ti}+\right.$ tek $]$

Den Dikken (2006) revises this structure and proposes that within the possessive DP of the Accusative pronoun, the pronoun itself is the possessor, while the posses- 
sum is a defective noun that is silent with a plural possessor and $-g$ with a singular possessor. ${ }^{29}$ This accounts for the appearance of the mysterious - $g$ element in en- $g$ em 'I-g-POSS.1SG' (me) and té-g-ed 'you-g-POSS.2SG' (you.sg) but not in mi-nket 'we-POSS.1PL-ACC' (us) and ti-tek-et 'you-POSS.2PL-ACC' (you.pl). The partial structures of second person singular and plural Accusative pronouns are shown in (86). The presence of the possessive agreement is accounted for because the possessor is a pronoun, and a possessum agrees for the $\phi$-features of pronouns. ${ }^{30}$

Den Dikken (2006:ex. (25))

a. $\left[F P[N P\right.$ te $]\left[F^{\prime} \mathrm{F} \ldots[N P-\mathrm{g}]\right.$

b. $\left[F P[N P\right.$ ti $]\left[F^{\prime} \mathrm{F} \ldots[N P \emptyset]\right.$

What is common to the two versions of the analysis is that Hungarian first and second person object pronouns are complex DPs that are internally structured as possessed nominals. There is clearly more to be said about why this complex structure is necessary for Hungarian first and second person pronouns, and why én 'I', $t e$ 'you(sg)', $m i$ 'we', and $t i$ 'you(pl)' cannot sit in the direct object position all by themselves. However, the data do justify Den Dikken's approach: to all intents and purposes, first and second person object pronouns look like possessed nominals.

Den Dikken's analysis can successfully capture a number of curiosities of Hungarian Accusative pronouns. Firstly, it explains the obligatory presence of the possessive agreement on the pronoun: there is a pronominal possessor in the structure, and so the possessum agrees with it. Secondly, the analysis gives insight into why the case marker itself is omitted in first and second person singular object pronouns. Accusative case is obligatory on Hungarian objects, except if the object has a first or second person pronominal possessor. In this case the Accusative case marker is freely droppable.

Nem talál-om a könyv-et/*a könyv. not find-1SG the book-ACC/the book 'I do not find the book.'
a. Nem talál-om a könyv-em-(et)/könyv-ünk-(et).
not find-1SG the book-POSS.1SG-ACC/book-POSS.1PL-ACC
'I do not find my/our book.'
b. Nem talál-om a könyv-ed-(et)/könyv-etek-(et).
not find-1SG the book-POSS.2SG-ACC/book-POSS.2PL-ACC
'I did not find your(sg/pl) book.'

Finally, and most importantly for our purposes, this analysis also gives a natural account of the order of the case marker and the possessive agreement. First and second person object pronouns in Hungarian are ordinary possessive structures; so the order of the agreement and the case marker is correctly predicted to be identical to the order in ordinary possessive object DPs (90), with the case following the agreement.

\footnotetext{
${ }^{29}$ See also Den Dikken (2013) for further development of this idea.

${ }^{30}$ The structures in (86) are reminiscent of the camouflage structures studied in Collins et al. (2008), where 'your highness' is a possessive structure with a pronominal possessor, and has the same meaning as 'you.'
} 
(89)

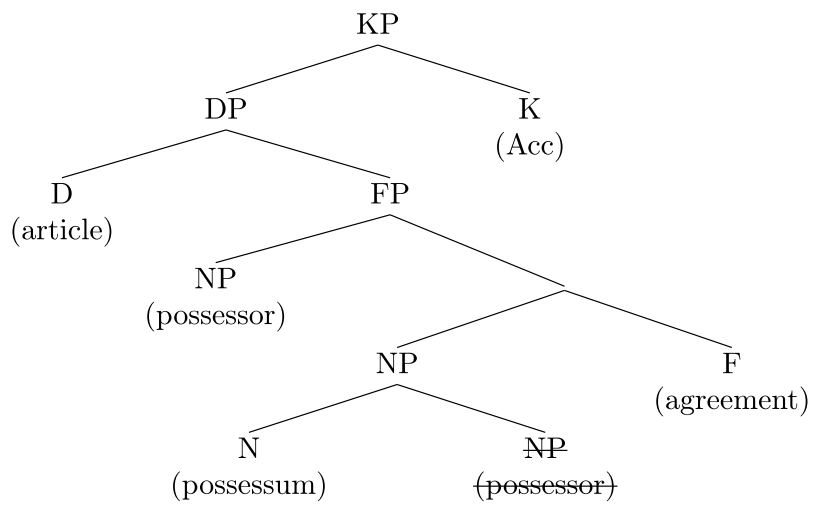

(90) a (mi) fej-ünk-et

the we head-POSS.1SG-ACC

'our head'

(91) mi-nk-et

we-POSS.1SG-ACC

'us'

We can thus conclude that whenever possessive agreement unexpectedly appears on a pronoun (be it in Accusative DPs or oblique PPs), it is because the relevant structure has a hidden possessive core.

\section{Conclusions}

In this paper I sought to answer the following questions regarding Hungarian pronouns bearing an oblique case or a caselike P. (1) Why is possessive agreement obligatory? (2) Why is the order of case and agreement reversed with respect to ordinary possessive structures? (3) Why is the pronoun optional in oblique PPs?

(én)-től-em

I-ABL-POSS.1SG

'from me'

az (én) sütemény-em-től

the I pastry-POSS.1SG-ABL

'from my pastry'

I argued that adopting a possessive structure for PPs, whereby the Ground is the possessor of a silent PLACE noun, can successfully account for the questions raised above. (1) In Hungarian the possessum agrees with its pronominal possessors, and so the PLACE noun also agrees with its pronominal possessors, that is, pronominal Grounds. (2) The order of the agreement and case are reversed in (92) and (93) because these agreements arise from two different possessive relationships: in (92) the agreement is between PLACE and the Ground, while the agreement in (93) is internal to the Ground. (3) The pronoun is optional because pronominal possessors may undergo pro-drop in the language. 
As for Accusative pronouns, they also bear possessive agreement, but unlike with oblique cases and caselike Ps, Accusative case follows the agreement.

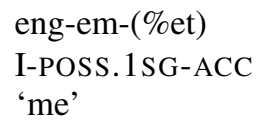

For these pronouns I adopted the approach of Den Dikken et al. (2001), Den Dikken (2004) and Den Dikken (2006), which holds that Accusative pronouns have an underlying possessive structure. (94) thus has the same morpheme order as (93) because there is a structural parallel between the internal structure of the Ground in (93) and the internal structure of the pronoun in (94).

Acknowledgements I thank Pavel Caha, Marcel den Dikken, Jacopo Garzonio and Silvia Rossi for feedback and support during various stages of this research. I also thank two NLLT reviewers and the handling editor, Julie Anne Legate, for useful comments. All remaining errors are mine.

Work on this paper was supported by the Hungarian Scientific Research Fund's grants OTKA NK 100804, OTKA 118079 and OTKA 125206, as well as the postdoctoral fellowship programme of the Hungarian Academy of Sciences. Unless otherwise noted, the source of the data is my own native speaker intuition.

Open Access This article is distributed under the terms of the Creative Commons Attribution 4.0 International License (http://creativecommons.org/licenses/by/4.0/), which permits unrestricted use, distribution, and reproduction in any medium, provided you give appropriate credit to the original author(s) and the source, provide a link to the Creative Commons license, and indicate if changes were made.

\section{References}

Aboh, Enoch O. 2005. The category P: The Kwa paradox. Linguistic Analysis 32 (3-4): 615-646.

Aboh, Enoch O. 2010. The P route. In Mapping spatial PPs, eds. Guglielmo Cinque and Luigi Rizzi. The cartography of syntactic structures 6, 225-260. Oxford: Oxford University Press.

Asbury, Anna. 2008. The morphosyntax of case and adpositions. PhD diss., University of Utrecht.

Asbury, Anna, Berit Gehrke, and Veronika Hegedús. 2007. One size fits all: Prefixes, particles, adpositions and cases as members of the category P. In UiL OTS yearbook 2006, ed. Cem Keskin, 1-17. Utrecht: Utrecht University.

Bartos, Huba. 1999. Morfoszintaxis és interpretáció. A magyar inflexiós jelenségek szintaktikai háttere [Morphosyntax and interpretation. The syntactic background of Hungarian inflexional phenomena]. PhD diss., Eötvös University.

Bartos, Huba. 2000. Az inflexiós jelenségek szintaktikai háttere [The syntactic background of inflexional phenomena]. In Strukturális magyar nyelvtan 3. Morfológia [Hungarian structural grammar 3. Morphology], ed. Ferenc Kiefer, 653-761. Budapest: Akadémiai Kiadó.

Bartos, Huba. 2001. Mutató névmási módosítók a magyarban: egyezés vagy osztozás? [Demonstrative modifiers in Hungarian: agreement or feature sharing?]. In Újabb tanulmányok a strukturális magyar nyelvtan és a nyelvtörténet köréból. Kiefer Ferenc tiszteletére barátai és tanítványai [Recent studies in Hungarian structural grammar and diachronic linguistics. In honour of Ferenc Kiefer, from his friends and students], eds. Marianne Bakró-Nagy, Zoltán Bánreti, and Katalin É. Kiss, 19-41. Budapest: Osiris.

Borsley, Robert D., Maggie Tallerman, and David Willis. 2007. The syntax of Welsh. Cambridge: Cambridge University Press.

Botwinik-Rotem, Irena. 2008. Why are they different? An exploration of Hebrew locative PPs. In Syntax and semantics of Spatial P, eds. Anna Asbury, Jakub Dotlačil, Berit Gehrke, and Rick Nouwen. Linguistik Aktuell / Linguistics Today 120, 331-364. Amsterdam: Benjamins.

Botwinik-Rotem, Irena, and Arhonto Terzi. 2008. Greek and Hebrew locative prepositional phrases: A unified case driven account. Lingua 118: 399-424. 
Carstens, Vicki. 2008. DP in Bantu and Romance. In The Bantu-Romance connection, eds. Cécile de Cat and Katherine Demuth. Linguistik Aktuell /Linguistics Today 131, 131-165. Amsterdam: Benjamins.

Cinque, Guglielmo. 2010a. Mapping spatial PPs: An introduction. In Mapping spatial PPs: The cartography of syntactic structures 6, eds. Guglielmo Cinque and Luigi Rizzi, 3-25. New York: Oxford University Press.

Cinque, Guglielmo. 2010b. The syntax of adjectives: A comparative study. Linguistic inquiry monographs 57. Cambridge: MIT Press.

Collins, Chris. 2007. Home sweet home. NYU Working Papers in Linguistics 1: 1-34.

Collins, Chris, Simanique Moody, and Paul Postal. 2008. An AAE camouflage construction. Language 84: 29-68.

Creissels, Denis. 2006. Suffixes casuels et postpositions en hongrois. Bulletin de la société linguistique de Paris 101 (1): 225-272.

Dékány, Éva. 2011. A profile of the Hungarian DP. The interaction of lexicalization, agreement and linearization with the functional sequence. PhD diss., University of Troms $\emptyset$.

Dékány, Éva. 2015. The syntax of anaphoric possessives in Hungarian. Natural Language and Linguistic Theory 33 (4): 1121-1168.

Dékány, Éva, and Veronika Hegedûs. 2015. Word order variation in Hungarian PPs. In Approaches to Hungarian 14: Papers from the 2013 Piliscsaba conference, eds. Katalin É. Kiss, Balázs Surányi, and Éva Dékány, 95-120. Amsterdam: Benjamins. doi:10.1075/atoh.14.04dek.

Den Dikken, Marcel. 1999. On the structural representation of possession and agreement. The case of (anti-)agreement in Hungarian possessed nominal phrases. In Crossing boundaries: Theoretical advances in Central and Eastern European languages, ed. István Kenesei, 137-178. Amsterdam: Benjamins.

Den Dikken, Marcel. 2004. Agreement and 'clause union.' In Verb clusters: A study of Hungarian, German and Dutch, eds. Katalin É. Kiss and Henk van Riemsdijk. Linguistik Aktuell/Linguistics Today 69, 445-498. Amsterdam: Benjamins.

Den Dikken, Marcel. 2006. Where Hungarians agree (to disagree): The fine structure of 'phi' and 'art.' Ms., CUNY Graduate Center.

Den Dikken, Marcel. 2010. On the functional structure of locative and directional PPs. In Mapping spatial PPs, eds. Guglielmo Cinque and Luigi Rizzi. The Cartography of Syntactic Structures 6, 74-126. New York: Oxford University Press.

Den Dikken, Marcel. 2013. $\phi$-Features. Handout, CUNY syntax seminar Fall 2013.

Den Dikken, Marcel, and Éva Dékány. to appear. A restriction on recursion. Syntax.

Den Dikken, Marcel, Anikó Lipták, and Zsófia Zolenszky. 2001. On inclusive reference anaphora: New perspectives from Hungarian. In West Coast Conference on Formal Linguistics (WCCFL) 20, eds. Karine Megerdoomian and Leora Anne Bar-el, 137-149. Somerville: Cascadilla Press.

É. Kiss, Katalin. 1987. Configurationality in Hungarian. Dordrecht: Reidel.

É. Kiss, Katalin. 1998. Verbal prefixes or postpositions? Postpositional aspectualizers in Hungarian. In Approaches to Hungarian 6, eds. Caspar de Groot and István Kenesei, 123-148. Szeged: JATE.

É. Kiss, Katalin. 1999. Mi tartozik a névutók osztályába? [What belongs to the category of postpositions?]. Magyar nyelvjárások 37: 167-172. http://mnytud.arts.unideb.hu/mnyj/37/index.html. Accessed 10 August 2017.

É. Kiss, Katalin. 2000. The Hungarian NP is like the English NP. In Approaches to Hungarian 7: Papers from the Pécs conference, eds. Gábor Alberti and István Kenesei, 119-150. Szeged: JATE.

É. Kiss, Katalin. 2001. A főnévi igenév személyragozásának kérdéseirôl [On infinitival agreement]. In Újabb tanulmányok a strukturális magyar nyelvtan és nyelvtörténet köreból [New studies in Hungarian structural grammar and diachrony], eds. Marianne Bakró-Nagy, Zoltán Bánreti, and Katalin É. Kiss, 249-273. Budapest: Osiris.

É. Kiss, Katalin. 2002. The syntax of Hungarian. Cambridge: Cambridge University Press.

É. Kiss, Katalin. 2014. Ways of licensing Hungarian external possessors. Acta Linguistica Hungarica 61 (1): 45-68.

Grimshaw, Jane. 2000. Extended projection and locality. In Lexical specification and insertion, eds. Peter Coopmans, Martin Everaert, and Jane Grimshaw. Current issues in linguistic theory 197, 115-133. Amsterdam: Benjamins.

Hegedûs, Veronika. 2006. Hungarian spatial PPs. Nordlyd: Troms $\phi$ University Working Papers in Linguistics 33 (2): 220-233.

Hegedűs, Veronika. 2013. Non-verbal predicates and predicate movement in Hungarian. PhD diss., Tilburg University. 
Hegedús, Veronika. 2014. The cyclical development of Ps in Hungarian. In The evolution of functional left peripheries in Hungarian, ed. Katalin É. Kiss. Oxford studies in diachronic and historical linguistics, 122-147. Oxford: Oxford University Press.

Hegedús, Veronika. 2015. The grammaticalization of postpositions in Old Hungarian. In Syntax over time, eds. Theresa Biberauer and George Walkden. Oxford linguistics, 72-85. Oxford: Oxford University Press.

Jackendoff, Ray. 1983. Semantics and cognition. Cambridge: MIT Press.

Julien, Marit. 2002. Syntactic heads and word formation. Oxford studies in comparative syntax. New York: Oxford University Press.

Julien, Marit. 2007. On the relation between morphology and syntax. In The Oxford handbook of linguistic interfaces, eds. Gillian Ramchand and Charles Reiss, 209-238. Oxford: Oxford University Press.

Katz, Jerrold J., and Paul M. Postal. 1964. An integrated theory of linguistic descriptions, 1970 edn. MIT press research monographs 26. Cambridge: MIT Press.

Kayne, Richard S. 2004. Here and there. In Lexique, syntaxe et lexique-grammaire, 253-275. Amsterdam: Benjamins.

Kenesei, István. 1992. Az alárendelt mondatok szerkezete [The structure of embedded clauses]. In Strukturális magyar nyelvtan 1. Mondattan. [Hungarian structural grammar 1. Syntax], ed. Ferenc Kiefer, 529-714. Budapest: Akadémiai Kiadó.

Kiefer, Ferenc. 2000. A ragozás [Inflection]. In Strukturális magyar nyelvtan 3. Morfológia [Hungarian structural grammar 3. Morphology], ed. Ferenc Kiefer, 569-619. Budapest: Akadémiai Kiadó.

Koopman, Hilda. 2010. Prepositions, postpositions, circumpositions, and particles. In Mapping spatial PPs, eds. Guglielmo Cinque and Luigi Rizzi. The cartography of syntactic structures 6, 26-73. Oxford: Oxford University Press.

Laczkó, Tibor. 1995. The syntax of Hungarian Noun Phrases. A Lexical-Functional approach. Metalinguistica 2. Frankfurt am Main: Peter Lang.

Laczkó, Tibor. 2007. On elliptical noun phrases in Hungarian. In Lexical-Functional Grammar (LFG)07 Conference, eds. Miriam Butt and Tracy Holloway King, 323-342. Stanford: CSLI. http://web.stanford.edu/group/cslipublications/cslipublications/LFG/12/papers/lfg07laczko1.pdf. Accessed 10 August 2017.

Lipták, Anikó, and Andés Saab. 2014. No N-raising out of NPs in Spanish: Ellipsis as a diagnostic of head movement. Natural Language and Linguistic Theory 32 (4): 1247-1271.

Lipták, Anikó, and Andés Saab. 2016. Movement and deletion after syntax: Licensing by inflection reconsidered. Studia Linguistica 70 (1): 66-108.

Marácz, László. 1984. Postposition stranding in Hungarian. In Groninger arbeiten zur germanistischen linguistik 24, eds. Werner Abraham and Sjaak de Mey, 127-161. Groningen: University of Groningen.

Marácz, László. 1986. Dressed or naked: The case of the PP in Hungarian. In Topic, focus and configurationality, eds. Abraham Werner and Sjaak de Meij, 223-252. Amsterdam: Benjamins.

Marácz, László. 1989. Asymmetries in Hungarian. PhD diss., Rijksuniversität Groningen.

Moravcsik, Edith. 2003. Inflectional morphology in the Hungarian noun phrase: A typological assessment. In Noun phrase structure in the languages of Europe, ed. Frans Plank, 113-252. Berlin: de Gruyter.

Nchare, Abdoulaye Laziz. 2012. The grammar of Shupamem. PhD diss., New York University.

Nchare, Abdoulaye Laziz, and Arhonto Terzi. 2014. Licensing silent structure: The spatial prepositions of Shupamem. Natural Language and Linguistic Theory 32 (2): 673-710.

Nikolaeva, Irina. 1999. Ostyak. Languages of the world materials 305. Muenchen: Lincom Europa.

Nikolaeva, Irina. 2014. A grammar of Tundra Nenets. Mouton grammar library 65. Berlin: de Gruyter.

Noonan, Máire. 2010. À to zu. In Mapping spatial PPs, eds. Guglielmo Cinque and Luigi Rizzi, 161-195. Oxford: Oxford University Press.

Ouali, Hamid. 2011. Agreement, pronominal clitics and negation in Tamazight Berber. Continuum studies in theoretical linguistics. London: Continuum.

Ouhalla, Jamal. 1991. Functional categories and parametric variation. London: Routledge.

Pantcheva, Marina. 2008. The place of PLACE in Persian. In Syntax and semantics of Spatial P, eds. Anna Asbury, Jacub Dotlačil, Berit Gehrke, and Rick Nouwen, 305-330. Amsterdam: Benjamins.

Pantcheva, Marina. 2011. Decomposing Path. PhD diss., University of Troms $\varnothing$.

Payne, John, and Erika Chisarik. 2000. Demonstrative constructions in Hungarian. In Approaches to Hungarian 7: Papers from the Pécs conference, eds. Gábor Alberti and István Kenesei, 181-198. Szeged: JATE. 
Rákosi, György. 2010. On snakes and locative binding in Hungarian. In Lexical-Functional Grammar (LFG) 10, eds. Miriam Butt and Tracy Holloway King, 395-415. Stanford: CSLI.

Rákosi, György. 2012. A magyar birtokos szerkezetû viszonyjelölőkrôl, avagy kígyók szájfénnyel és esernyővel [On Hungarian locatives with a possessive structure, or snakes with lipbalms and umbrellas]. In Nyelvelmélet és dialektológia [Language theory and dialectology], eds. Katalin É. Kiss and Attila Hegedús, 154-173. Pilliscsaba: PPKE BTK.

Rákosi, György. 2014. A case of disagreement. On plural reduplicating particles in Hungarian. In The evidential basis of linguistic argumentation, eds. András Kertész and Csilla Rákosi. Studies in language companion series 153, 179-198. Amsterdam: Benjamins. doi:10.1075/slcs.153.07rak.

Rákosi, György, and Tibor Laczkó. 2008. On the categorial status of agreement-marked infinitives in Hungarian. In Approaches to Hungarian 10, eds. Christopher Piñón and Szentgyörgyi Szilárd, 149-172. Budapest: Akadémiai Kiadó.

Rákosi, György, and Tibor Laczkó. 2011. Inflecting spatial Ps as shadows of the past in Hungarian. In Lexical-Functional Grammar ( $L F G$ ) 11, eds. Miriam Butt and Tracy Holloway King, 440-460. Stanford: CSLI.

Riemsdijk, Henk C., and Riny Huybregts. 2002. Location and locality. In Progress in grammar: Articles at the 20th anniversary of the Comparison of Grammatical Models Group in Tilburg, eds. Marc van Oostendorp and Elena Anagnostopoulou, 1-23. Amsterdam: Meertens Institute.

Riese, Timothy. 2001. Vogul. Languages of the world materials 158. Muenchen: Lincom Europa.

Roy, Isabelle, and Peter Svenonius. 2009. Complex prepositions. In Autour de la préposition. Actes du Colloque International de Caen (20-22 septembre 2007), eds. François Jacques, Eric Gilbert, Claude Guimier, and Maxi Krause, 105-116. Caen: Presses Universitaires de Caen.

Spencer, Andrew J., and Gregory T. Stump. 2013. Hungarian pronominal case and the dichotomy of content and form in inflectional morphology. Natural Language and Linguistic Theory 31 (4): 12071248 .

Surányi, Balázs. 2009a. Adpositional preverbs, chain reduction and phases. In Approaches to Hungarian 11: Papers from the 2007 New York Conference, eds. Marcel den Dikken and Robert M. Vago, 217250. Amsterdam: Benjamins.

Surányi, Balázs. 2009b. "Incorporated" locative adverbials in Hungarian. In Adverbs and adverbial adjuncts at the interfaces, ed. Katalin É. Kiss, 39-74. Berlin: de Gruyter.

Svenonius, Peter. 2006. The emergence of Axial Parts. Nordlyd: Troms $\phi$ University Working Papers in Linguistics 33 (1): 49-77.

Svenonius, Peter. 2010. Spatial P in English. In Mapping spatial PPs, eds. Guglielmo Cinque and Luigi Rizzi. The cartography of syntactic structures 6, 127-160. Oxford: Oxford University Press.

Szabolcsi, Anna. 1992. A birtokos szerkezet és az egzisztenciális mondat [The possessive construction and existential sentences]. Budapest: Akadémiai Kiadó.

Szabolcsi, Anna. 1994. The Noun Phrase. In The syntactic structure of Hungarian, eds. Ferenc Kiefer and Katalin É. Kiss. Syntax and semantics 27, 179-275. New York: Academic Press.

Szabolcsi, Anna, and Tibor Laczkó. 1992. A fônévi csoport szerkezete [The structure of the noun phrase]. In Strukturális magyar nyelvtan 1. Mondattan [Hungarian structural grammar 1. Syntax], ed. Ferenc Kiefer, 181-298. Budapest: Akadémiai Kiadó.

Terzi, Arhonto. 2005. Locative prepositions as possessums. In Selected papers from the 16th International Symposium on Theoretical and Applied Linguistics, eds. Marina Mattheoudakis and Angeliki PsaltouJoycey, 133-144. Thessaloniki: University of Thessaloniki.

Terzi, Arhonto. 2008. Locative prepositions as modifiers of an unpronounced noun. In West Coast Conference on Formal Linguistics (WCCFL) 26, eds. Charles B. Chang and Hannah J. Haynie, 470-471. Somerville: Cascadilla Press.

Terzi, Arhonto. 2010. Locative prepositions and Place. In Mapping spatial PPs, eds. Guglielmo Cinque and Luigi Rizzi. The cartography of syntactic structures 6, 196-224. Oxford: Oxford University Press.

Tóth, Ildikó. 2000. Inflected infinitives in Hungarian. PhD diss., University of Tilburg.

Tóth, Ildikó. 2002. Can the Hungarian infinitive be possessed? In Approaches to Hungarian 8, eds. István Kenesei and Péter Siptár, 134-160. Budapest: Akadémiai Kiadó.

Trommer, Jochen. 2008. "Case suffixes," postpositions and the phonological word in Hungarian. Linguistics 46 (2): 403-437.

Zwarts, Joost, and Yoad Winter. 2000. Vector space semantics: A model-theoretic analysis of locative prepositions. Journal of Logic, Language and Information 9: 169-211. 